San Jose State University

SJSU ScholarWorks

Master's Theses

Master's Theses and Graduate Research

1991

\title{
Approaches to the synthesis of a mechanism-based inhibitor of mevalonate-5-pyrophosphate decarboxylase and a new sysnthesis of 10-phenylanthrone
}

Yanzhou Liu

San Jose State University

Follow this and additional works at: https://scholarworks.sjsu.edu/etd_theses

\section{Recommended Citation}

Liu, Yanzhou, "Approaches to the synthesis of a mechanism-based inhibitor of mevalonate-5-pyrophosphate decarboxylase and a new sysnthesis of 10-phenylanthrone" (1991). Master's Theses. 140.

DOI: https://doi.org/10.31979/etd.h9rp-kfy2

https://scholarworks.sjsu.edu/etd_theses/140

This Thesis is brought to you for free and open access by the Master's Theses and Graduate Research at SJSU ScholarWorks. It has been accepted for inclusion in Master's Theses by an authorized administrator of SJSU ScholarWorks. For more information, please contact scholarworks@sjsu.edu. 


\section{INFORMATION TO USERS}

This manuscript has been reproduced from the microfilm master. UMI films the text directly from the original or copy submitted. Thus, some thesis and dissertation copies are in typewriter face, while others may be from any type of computer printer.

The quality of this reproduction is dependent upon the quality of the copy submitted. Broken or indistinct print, colored or poor quality illustrations and photographs, print bleedthrough, substandard margins, and improper aligniment can adversely affect reproduction.

In the unlikely event that the author did not send UMI a complete manuscript and there are missing pages, these will be noted. Also, if unauthorized copyright material had to be removed, a note will indicate the deletion.

Oversize materials (e.g., maps, drawings, charts) are reproduced by sectioning the original, beginning at the upper left-hand corner and continuing from left to right in equal sections with small overlaps. Each original is also photographed in one exposure and is included in reduced form at the back of the book.

Photographs included in the original manuscript have been reproduced xerographically in this copy. Higher quality $6 "$ " 9 9" black and white photographic prints are available for any photographs or illustrations appearing in this copy for an additional charge. Contact UMI directly to order.

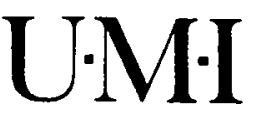

University Microfılms International

A Bell \& Howell Information Company

300 North Zeeb Road. Ann Arbor. MI 48106-1346 USA

$313 / 761-4700 \quad 800 / 521-0600$ 


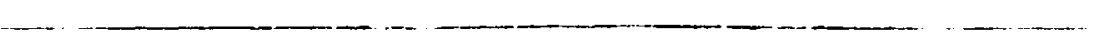


Order Number 1944286

Approaches to the synthesis of a mechanism-based inhibitor of mevalonate-5-pyrophosphate decarboxylase and a new synthesis of 10-phenylanthrone

Liu, Yanzhou, M.S.

San Jose State University, 1991 


\title{
APPROACHES TO THE SYNTHESIS OF A MECHANISM-BASED INHIBITOR OF MEVALONATE-5-PYROPHOSPHATE DECARBOXYLASE \\ and \\ A NEW SYNTHESIS OF 10-PHENYLANTHRONE
}

\author{
A Thesis \\ Presented to \\ The Faculty of the Department of Chemistry \\ San Jose State University \\ In Partial Fulfillment \\ of the Requirements for the Degree \\ Master of Science
}

By

Yanzhou Liu

May, 1991 


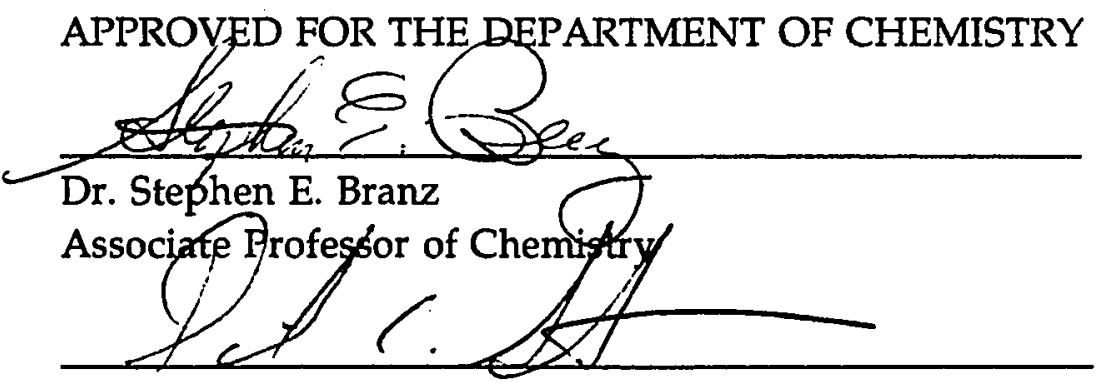

Dr. Daniel A. Straus

Assistant Professor of Chemistry

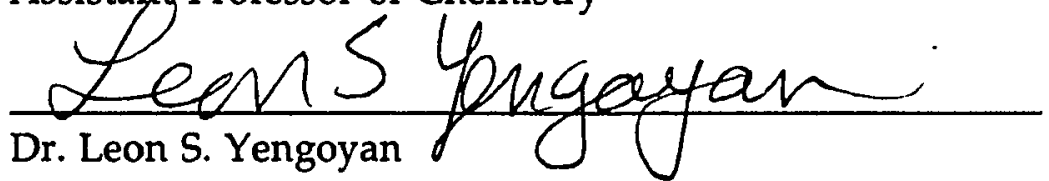

Professor of Chemistry

APPROVED FOR THE UNIVERSITY

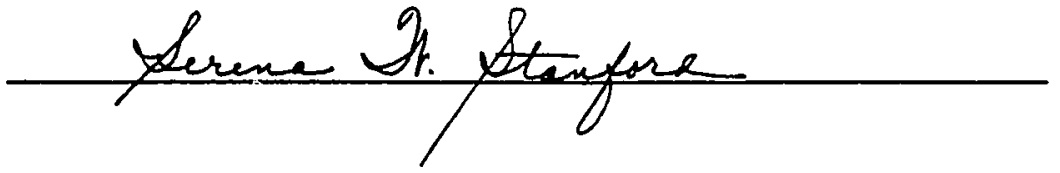




\begin{abstract}
APPROACHES TO THE SYNTHESIS OF A MECHANISM-BASED INHIBITOR OF MEVALONATE-5-PYROPHOSPHATE DECARBOXYLASE

and
\end{abstract}

\title{
A NEW SYNTHESIS OF 10-PHENYLANTHRONE
}

by Yanzhou Liu

Part I. The title enzyme catalyzes the conversion of mevalonic acid to isopentenyl pyrophosphate. The presumed metabolic intermediate is phosphorylated at the tertiary hydroxyl. Mevalonolactone is the classic source of mevalonate for metabolic studies. Replacement of the phosphate ester oxygen with a methylene carbon will produce an analog which is sterically similar yet is incapable of undergoing decarboxylative elimination. Several different approaches to the synthesis of this new inhibitor, 4-methyl-4phosphonomethyl-3,4,5,6-tetrahydro-2H-pyran-2-one, will be discussed.

Part II. In order to study the mechanism for the conversion of prephenic acid to para-hydroxyphenyllactic acid, a series of synthetic analogs of prephenic acid are needed. Our group has used substituted anthrones for this purpose. An improved synthesis of 10-phenylanthrone will be described. Additionally, new approaches and improvements in the existing synthetic methodology leading to 10,10-disubstituted anthrones will be outlined in this thesis. 


\section{Acknowledgements}

I thank all those who have helped me throughout this project. Prof. Leon Yengoyan made his creative suggestions on the biochemical aspects of my work. NIH/MBRS provided partial financial support. My special thanks go to my thesis advisor, Prof. Stephen E. Branz, who guided my experiments and kept this project moving with his enthusiasm.

I also thank my parents and my husband. I would like to present this thesis to them for their enormous support and sacrifice over the past three years. 


\section{Table of Contents}

Abstract

Acknowledgements $\quad$ iv

Table of Contents $\quad$ v

Part I. APPROACHES TO THE SYNTHESIS OF A MECHANISM BASED INHIBITOR OF MEVALONATE-5-PYROPHOSPHATE DECARBOXYLASE. $\quad 1$

Introduction $\quad \cdot \quad 2$

Results and Discussion $\quad 9$

$\begin{array}{lr}\text { Conclusion } & 20\end{array}$

Experimental $\quad 22$

6-Chlorosulfonylimino-3,6-dihydro-4-methyl-2H-pyran 22

5,6-Dihydro-4-methyl-2H-pyran-2-one $\quad 22$

Attempted Preparation of 4-Methyl-4-phosphonomethyl-3,4,5,6- 23 tetrahydro-2H-pyran-2-one

Attempted Preparation of 3-Methyl-3-phosphonomethyl- 25 cyclopentanone

4-Benzyloxy-2-butanone 26

Ethyl 5-benzyloxy-3-methyl-?-pentenoate 26

Attempted Preparation of Ethy! 5-Benzyloxy-3-methyl-3- 27 phosphonomethyl-2-puntanoate

2,2-Dimethyl-1,3-dioxane-4,6-dione (Meldrum's Acid) 28

Attempted Preparation of [2-(3-Benzyloxy)-butenylidene]-2,2- 29 dimethyl-1,3-dioxane-4,6-dione

Attempted Preparation of 5-Benzyloxy1-3-methyl-2-pentenonitrite 29

Diethylphosphonobromomethane 29

Attempted Preparation of Dimethyl 2-Methyl-3-carboethoxy- $\quad 30$ cyclopropylphosphate

4-Dimethylphenylsilyl-2-butanone 31

1-Cyano-4-dimethylphenylsilyl-2-methyl-1-butene and 1-Cyano- 32 4-dimethylphenylsilyl-2-methyl-2-butene (mixture)

References and Notes 
Part II. NEW SYNTHESIS OF 10-PHENYLANTHRONE 35

Introduction $\quad 36$

Results and Discussion $\quad 41$

$\begin{array}{ll}\text { Conclusion } & 46\end{array}$

Experimental $\quad 47$

2,4-Diphenyloxazole $\quad 47$

9,10-Epoxy-9,10-dihydro-10-phenylanthracene 48

10-Phenylanthrone 48

Attempted Preparation of 10-allyl-9.10-dihydro-10-phenyl-9- 49 trimethylsilyloxyanthracene

$\begin{array}{ll}\text { Tetraallyltin } & 49\end{array}$

References and Notes $\quad 50$ 


\section{PART I}

\section{APPROACHES TO THE SYNTHESIS OF A MECHANISM-BASED INHIBITOR OF MEVALONATE-5-PYROPHOSPHATE DECARBOXYLASE}




\section{Introduction}

Mevalonate-5-pyrophosphate decarboxylase is part of a complex system of enzymes which is found in the animals' livers. This enzyme is involved in an early step of cholesterol biosynthesis. It catalyzes a bimolecular reaction between mevalonate pyrophosphate and adenosine triphosphate (ATP) to form isopentenyl pyrophosphate, inorganic phosphate, adenosine diphosphate (ADP), and carbon dioxide $\left(\mathrm{CO}_{2}\right)$. Cholesterol plays a very important role in human health. Hypercholesterolaemia is considered to be a major risk factor in coronary artery diseases. ${ }^{1}$ This correlation explains the constant efforts made to understand the regulation and to find an inhibitor for cholesterol biosynthesis.

Considerable work has been done to understand the pathway of cholesterol biosynthesis. The major biosynthetic steps are: ${ }^{2}$

Acetate $\rightarrow$ Isoprenoid intermediates (5 carbon) $\rightarrow$ Squalene ( 30 carbon) $\rightarrow$ Cyclization product ( 30 carbon)

$\rightarrow$ Cholesterol (27 carbon)

There are about 15 steps in the entire process. Most of the key steps have been worked out by Konrad Bloch and John Cornforth, who both received Nobel prizes for their accomplishments. ${ }^{3}$ My research has concentrated on the conversion of mevalonate-5-pyrophosphate to isopentenyl pyrophosphate.

We are interested in making an inhibitor to study this decarboxylative elimination reaction. This inhibitor may act to decrease the amount of 
cholesterol which is produced in human tissue. Ours is not the first attempt to turn off cholesterol biosynthesis, 4,5 but we have taken a unique mechanism-based approach at this key point to the isoprenoids.
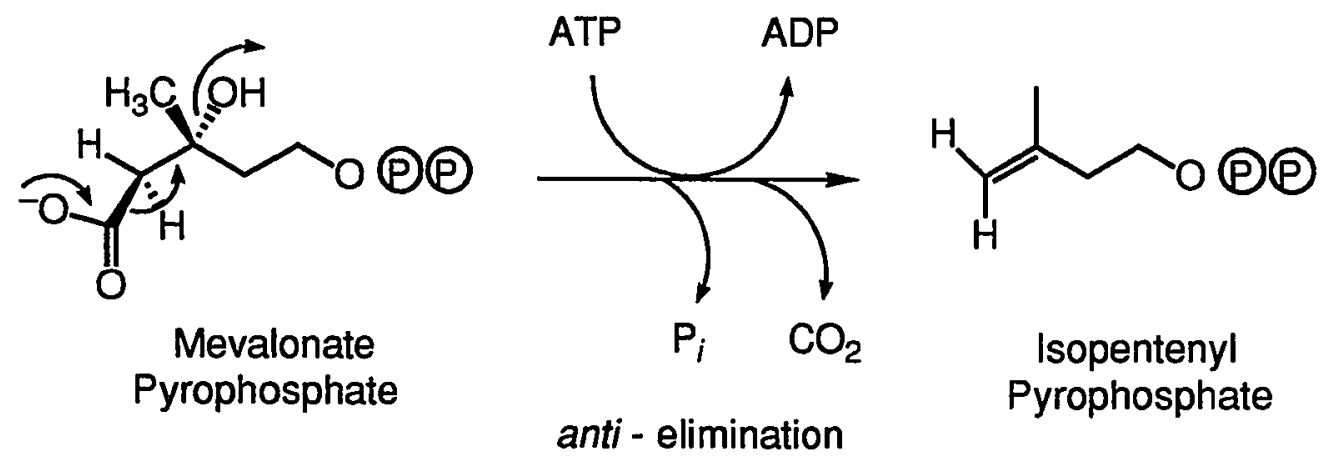

There are two possible mechanisms for this transformation. ${ }^{6}$ The first is a concerted mechanism which means that the reaction of ATP with mevalonate-5-pyrophosphate and the decarboxylative elimination happen simultaneously (Scheme I). Another possibility is that ATP may first phosphorylate the hydroxyl group of mevalonate-5-pyrophosphate, ${ }^{7}$ then lose the carboxyl in a second anti-elimination step (Scheme I). No direct evidence has been obtained for the existence of the intermediate 3-phosphonomevalonate-5-pyrophosphate which is required in a two step reaction sequence. 


\section{Scheme I}

Proposed Mechanisms for Decarboxylative Elimination

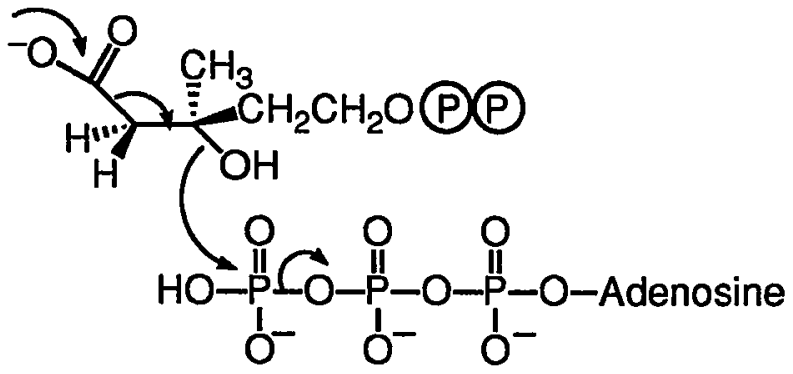

Concerted Mechanism

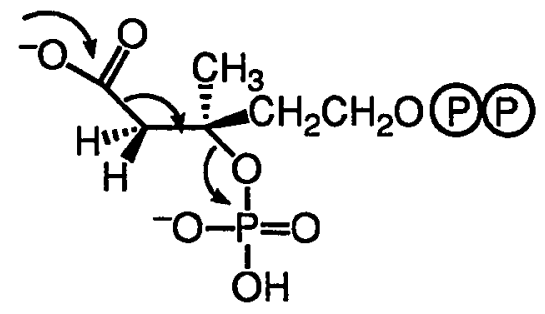

Presumed Intermediate in the two-step mechanism

3-Phosphonomevalonate-5-pyrophosphate

According to these mechanistic considerations, the structure of proposed inhibitor molecule is very similar to the presumed intermediate.

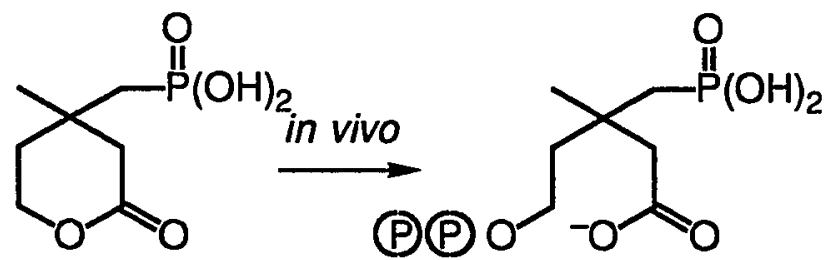

Synthetic Inhibitor<smiles>CC(CCO[Ga])(CC(=O)O[Ga])OP(=O)(O)O</smiles>

Presumed Intermediate 
We hope that this inhibitor molecule will compete with mevalonate pyrophosphate for the active site of the enzyme. Since the phosphate ester oxygen is replaced by a methylene group, the elimination cannot happen. Therefore, the whole sequence of cholesterol biosynthesis might stop at this point. Also, this research may provide some new information about the mechanism of this enzymatic reaction and allow us to learn more about the nature of the substrate binding site.

Our retrosynthetic strategy is summarized in Schemes II and III. Routes A, B, and $\mathrm{C}$ all involve conjugate additions to $\alpha, \beta$-unsaturated esters or ketones. Route $\mathbf{A}$ uses the unsaturated lactone $\mathbf{1}$ as the starting ester, whereas route $\mathbf{B}$ starts with an open-chain ester $\mathbf{2 a}$ or nitrile $\mathbf{2 b}$ which has either a $\delta$-benzyloxy or a $\delta$-phenyldimethylsilyl group. These $\delta$-substituents serve as masked hydroxyl groups. Route $\mathbf{C}$ begins with a cyclopentenone 3 . Route $\mathbf{D}$ uses the same lactone starting material as Route $\mathbf{A}$, but the key transformation is a carbene addition, not a conjugate addition. We have begun synthetic work on each of these four routes. We have had some success, but have not yet prepared our target inhibitor. The results for Routes A, Ba and C are summarized in Table I. Routes $\mathbf{B b}$ and $\mathbf{D}$ have been less thoroughly researched and hold the most promise of success. 
Scheme II

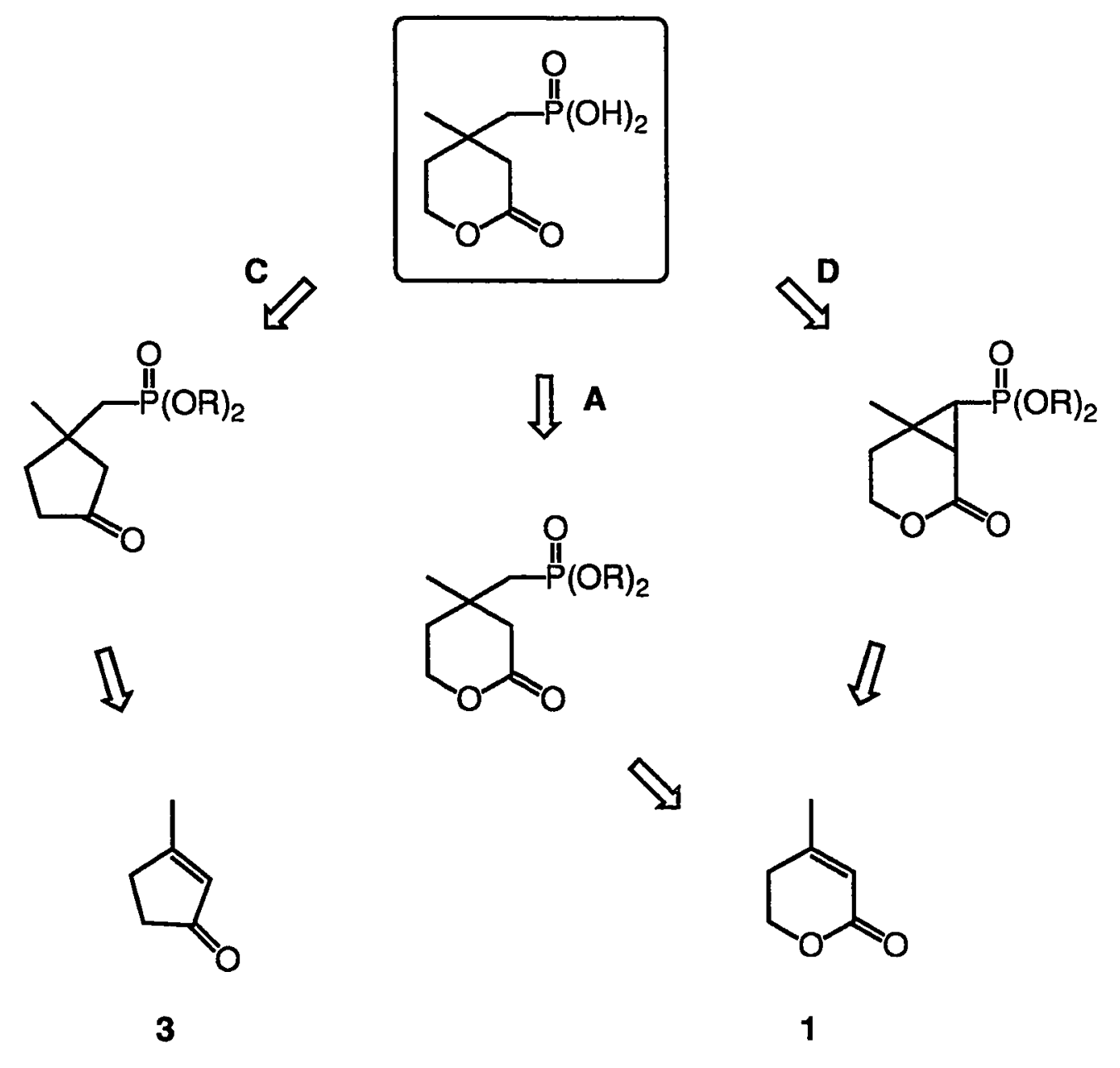




\section{Scheme III}

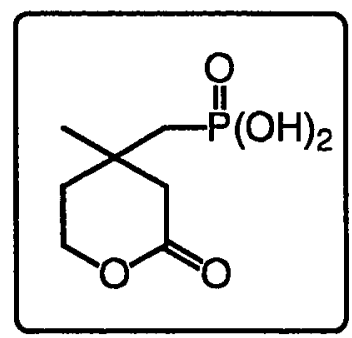

$\prod^{\mathbf{B}}$<smiles>CC(CCO)(CC(=O)O)CP(=O)(O)O</smiles>

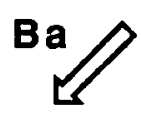<smiles>CCOC(=O)CC(C)(CCOc1ccccc1)CP(=O)(O)O</smiles><smiles>C=C</smiles><smiles>CCOC(=CC(C)CCOCc1ccccc1)CCO</smiles>

$2 a$

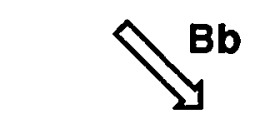<smiles>CCOC(=O)CC(C)(CC[SiH2]P)CP(=O)(O)O</smiles><smiles>[C]=C</smiles><smiles>C[SiH2]CC/C(C)=C\C#N</smiles>

$2 b$ 


\section{Table I}

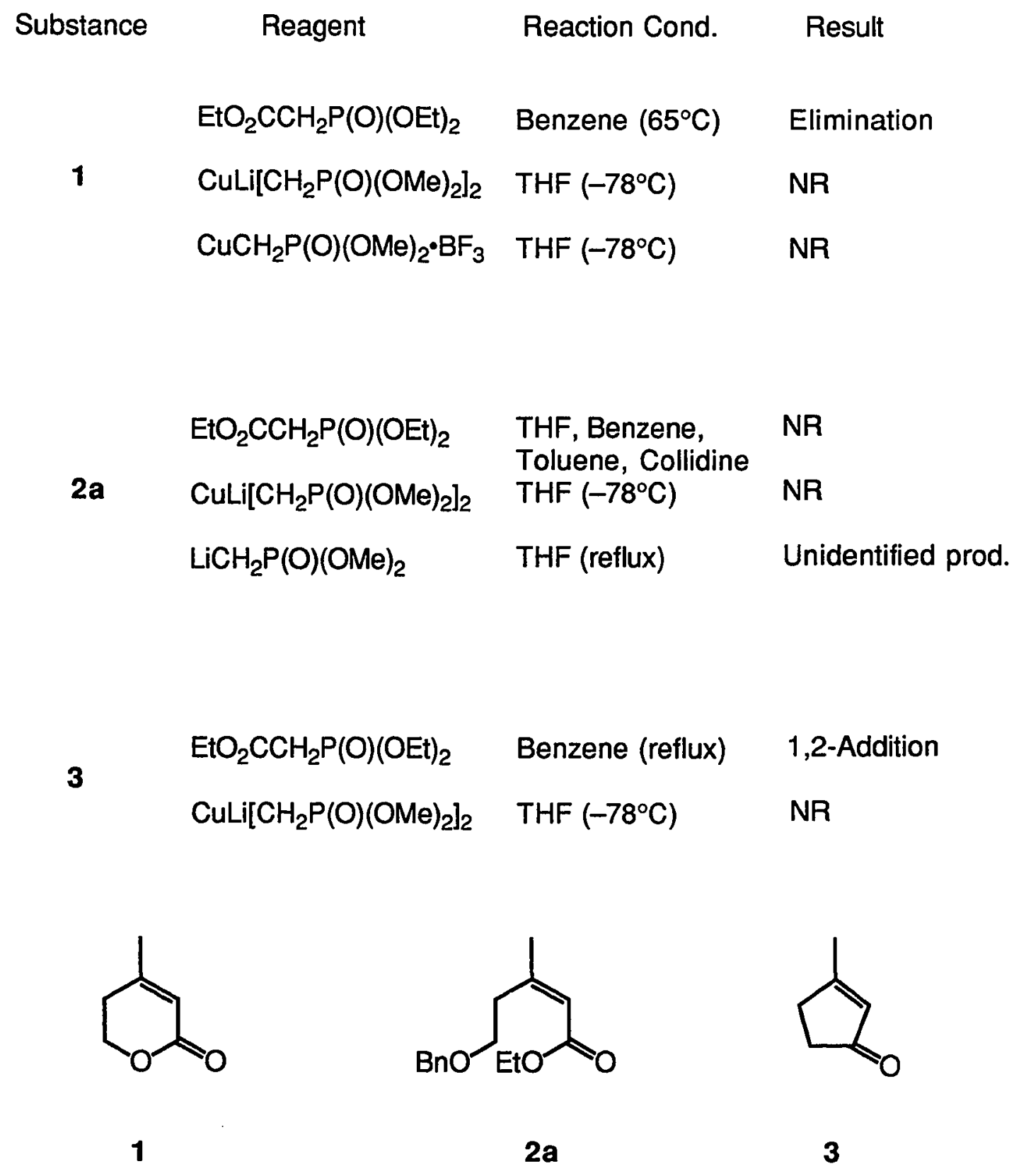




\section{Results and Discussion}

Once we had settled on the conjugate addition strategy, our first approach was the most straightforward. Route $\mathbf{A}$ requires the fewest steps from known starting materials and has no superfluous protection/deprotection steps. Scheme IV shows the preparation of lactone 1 by the cycloaddition of isoprene and chlorosulfonyl isocyanate, followed by rearrangement and hydrolysis.

\section{Scheme IV}<smiles>C=CC(=C)C</smiles>

Cycloaddition

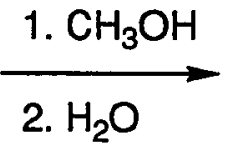

4<smiles>C=C(C)C1CC(=O)N1S(=O)(=O)OC</smiles><smiles>CC1=CC(=O)OCC1</smiles>

1

This lactone was treated with the enolate derived from triethyl phosphonoacetate. This stabilized nucleophile is the weakest base we used, but even so the elimination product was formed. The phosphono carbanion can remove the acidic $\gamma$-proton to give a conjugated enolate which undergoes a very rapid elimination reaction. We attribute the facility of this reaction to the fact that it is a symmetry allowed electrocyclic ring opening. The net result is that the anticipated Michael addition cannot happen (Scheme V). 


\section{Scheme V}

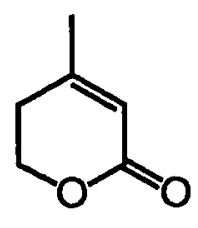

1
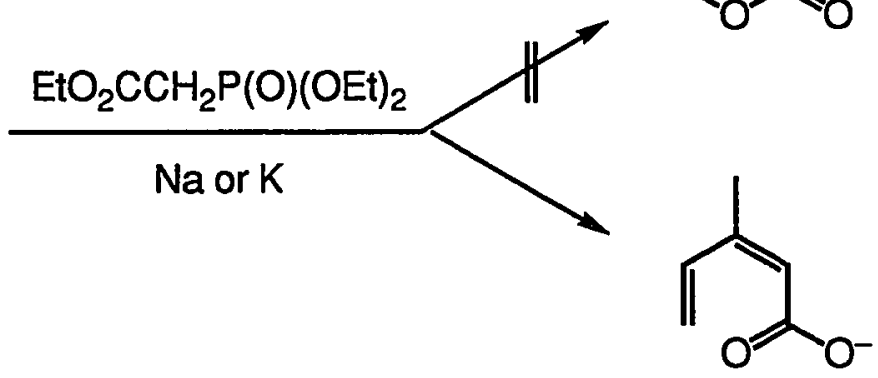

The mechanism of this elimination is shown below:<smiles>CC1=CC(=O)OCC1C</smiles>

In order to avoid this pericyclic elimination of lactone 1, we next settled on an open-chain analog $2 \mathrm{a}$ in which the $\delta$-hydroxy group was protected as a benzyl ether. Our plan called for eventual deprotection by catalytic hydrogenation. Scheme VI shows the synthesis of the previously unreported unsaturated ester 2a. Wittig-Horner reaction gave compound 2a in low yield. Because the reaction is carried out under basic conditions, elimination of benzyl alcohol is possible from either the starting compound 5 or the product 2a. The highest yield obtained for this reaction was $30 \%$. 


\section{Scheme VI}<smiles>OC[PH3+]</smiles>
excess
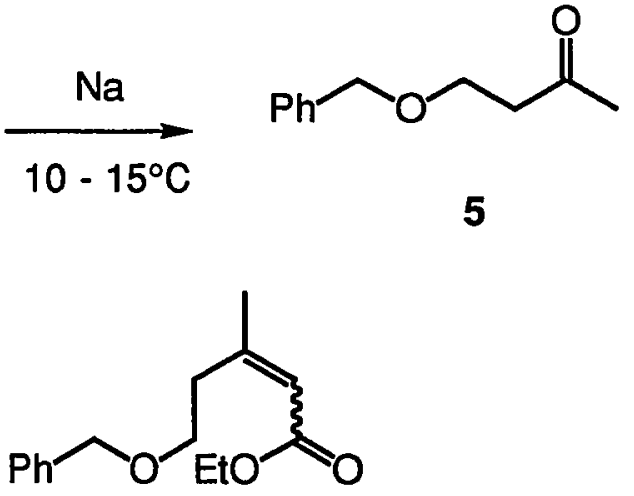

$2 a$

Three different nucleophiles under variety of reaction conditions (Table I) have all failed to give the desired conjugate addition with ester 2a. Both the carbanion derived from triethyl phosphonoacetate and the cuprate reagent derived from $\alpha$-lithio dimethyl methylphosphonate gave no reaction, even with forcing reaction conditions at high temperatures. When $\alpha$-lithio dimethyl methylphosphonate, which is much stronger base, was used directly as the nucleophile, the elimination of benzyl alcohol from starting ester 2a became the problem again. Although the products formed were not identified, they were probably derived from this elimination reaction or from direct 1,2-attack on the ester.

An effort to modify this ester $\mathbf{2 a}$ to be a better electrophile for 1,4-addition led to the design of the Meldrum's acid derivative $2 c$. There are two advantages if this molecule can be made. First, the two esters at the $\alpha$-position should 
make this molecule to be a much better Michael acceptor. Second, the geometrically enforced coplanarity of the ester carbonyls and the conjugated alkene should also favor 1,4-addition relative to 1,2-addition. Our plan was to produce $2 \mathrm{c}$ from reaction of Meldrum's acid with compound 5 in a transformation parallel to the well-known reaction of Meldrum's acid with aldehydes. Unfortunately, only the elimination product of compound 5, benzyl alcohol, was obtained under the standard reaction conditions for this aldol-type condensation reaction.

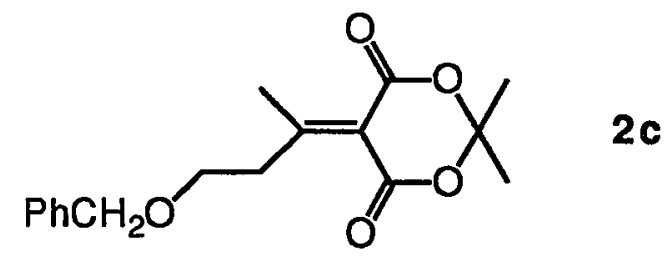

Our difficulties with elimination reactions eventually led us to a closely related synthetic strategy (Route $\mathbf{B b}$ ) in which a phenyldimethylsilyl group serves as a latent, or masked, hydroxyl group. It can be converted to a hydroxyl group with retention of configuration in two steps: ${ }^{8}$ protodesilylation of phenyl group with fluoboric acid, followed by a peracid mediated rearrangement.

Selective protodesilylation of the phenyl group (as opposed to one of the three alkyl groups) is not only required, but also expected based on literature precedent. 8 Scheme VII shows nitrile $2 \mathbf{b}$ which we have planned to synthesize as the starting material for Route $\mathbf{B b}$. This route is still being worked on. Silyl ketone 6 was prepared by the procedure of Fleming. 9 Unexpectedly, the proton NMR of this ketone showed broadening of the two 
methylene triplets. It may be that weak bonding between silicon and the carbonyl oxygen, which reduces the conformational mobility, is the cause of this unusual NMR behaviour.

\section{Scheme VII}<smiles>C=CC(C)=O</smiles>

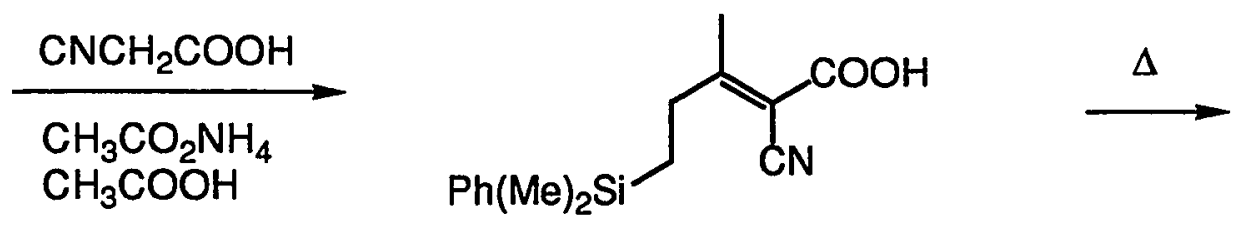

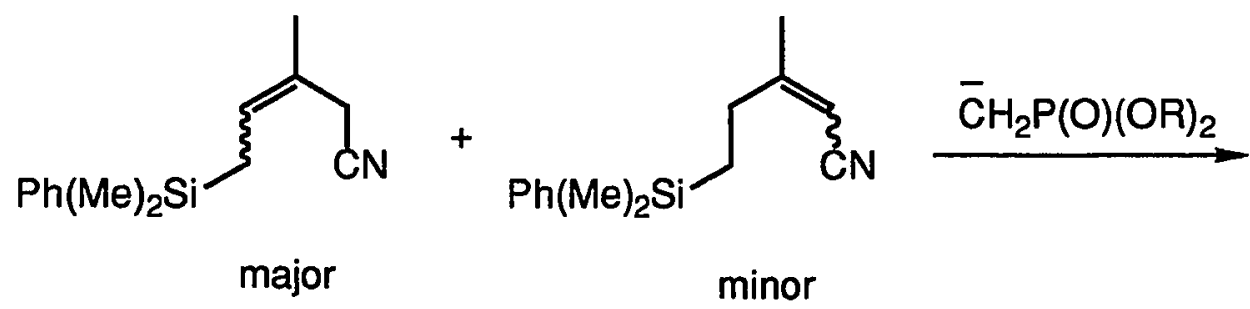<smiles>CC1(CP(=O)(O)O)CCOC(=O)C1</smiles>

Based on our previous difficulties with 1,4-additions to $\alpha, \beta$-unsaturated esters, we decided to incorporate one more structural variation, the change from an $\alpha, \beta$-unsaturated ester to an $\alpha, \beta$-unsaturated nitrile. A-1,3 strain in 
$\beta, \beta$-disubstituted esters, which tends to twist the ester out of conjugation with the double bond, is not present in the cyano analog. The $\alpha, \beta$-unsaturated nitrile $\mathrm{Ph}(\mathrm{Me})_{2} \mathrm{SiCH}_{2} \mathrm{CH}_{2} \mathrm{C}(\mathrm{Me})=\mathrm{CHCN}$ was prepared from the ketone 6 using a Perkin reaction. ${ }^{11}$ The NMR showed that the major product from the reaction was the $\beta, \gamma$-unsaturated nitrile and that the $\alpha, \beta$-unsaturated nitrile was only present as the minor product. (The major/minor ratio is $64 / 36$.) We hope that under the conditions required for conjugate addition, a basecatalyzed isomerization will generate the requisite form, the $\alpha, \beta$-unsaturated nitrile.

Route C started with 3-methyl-2-cyclopenten-1-one (3) which is commercially available. Our synthetic plan is shown on Scheme VIII.

Scheme VIII

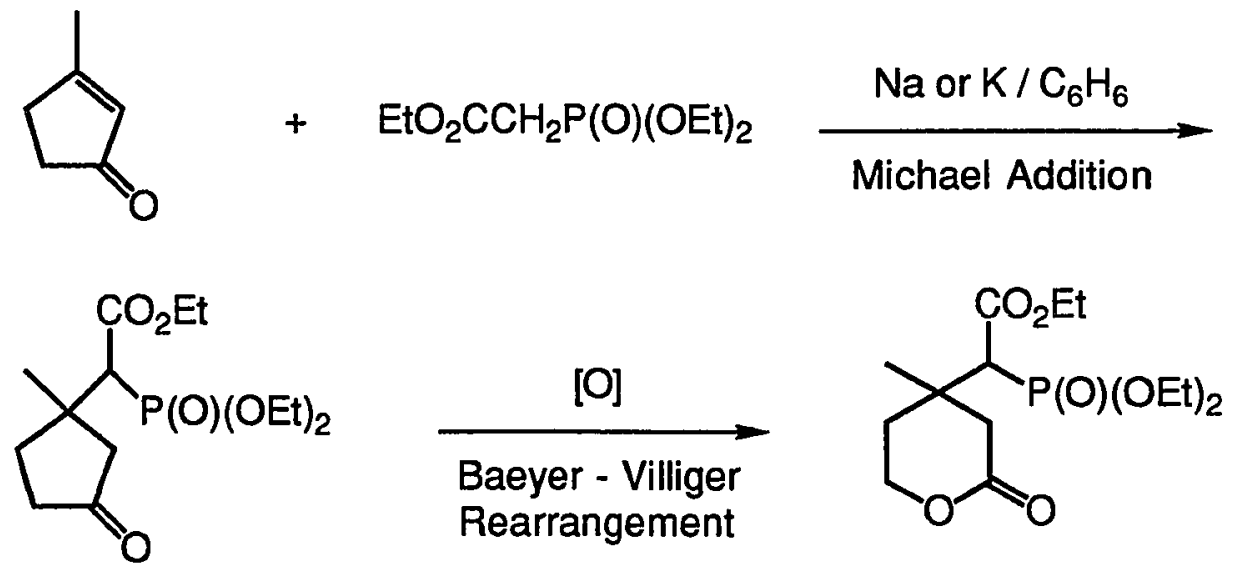

1. Hydrolysis

2. Decarboxylation<smiles>CC1(C[P+]([O])(O)O)CCOC(=O)C1</smiles> 
Usually, ketones give higher percentage of 1,4-addition product from Michael addition reactions, but in our experiments, only the 1,2-addition product was formed. Its hydrolysis product was obtained following workup as shown in Scheme IX.

\section{Scheme IX}

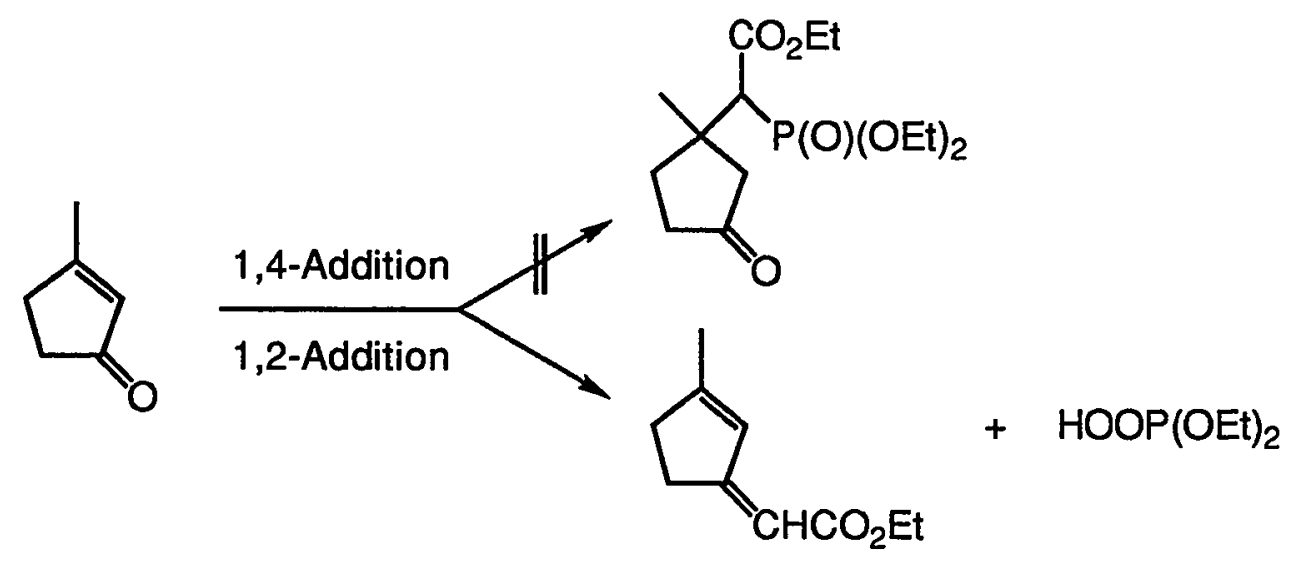

$\alpha, \beta$-Unsaturated ketones are more reactive with organo cuprate reagents than $\alpha, \beta$-unsaturated esters or nitriles, because they have lower reduction potentials. ${ }^{10}$ Since cuprate addition is thought to begin by a one-electron reduction, it makes sense that the more easily the compound is reduced, the more reactive it is toward cuprate reagents. Unfortunately, the cuprate reagent derived from $\alpha$-litho dimethyl methylphosphonate didn't react with ketone 3.

Thus far, we have discussed our efforts by focusing on the electrophilic partner in the proposed conjugate addition reactions. It is also possible to vary the nucleophilic partner. The triethyl phosphonoacetate carbanion is 
apparently such a highly stabilized enolate that it is not a very good nucleophile for 1,4-addition. Any of the many methyl phosphonate anions we have used can induce elimination of alkoxide from the starting lactone 1 or ester 2a. The phosphono acetate anion is often used in Wittig-Horner reactions with simple unconjugated ketones. Different solvents were used in an unsuccessful effort to enhance the reactivity of this stabilized anion.

Organometallic reagents (R-M) are highly useful for conjugate reaction to $\alpha, \beta$-unsaturated carbonyl compounds. Organocopper derivatives are the most widely used reagents and possess the most universal applicability. Previous researchers ${ }^{12}$ have shown that substituents on the double bonds of enones, enoate esters, or other related compounds frequently prevent the conjugate addition. Especially, it has been proven that $\beta$-substituents retard the 1,4-addition relative to the 1,2-addition, while an $\alpha$-substituent retards the 1,2-addition. Consequently, the regioselectivity must depend upon the size of substituents at the $\beta, \alpha$ and $\alpha^{\prime}$ positions and upon the nature of reagents. In this research, $\beta, \beta$-disubstituted esters and ketone were used; these are the worst substrates for conjugate addition. So far, the only literature report of conjugate addition to a $\beta, \beta$-dialkylester is from Yamamoto's group. ${ }^{13} \mathrm{~A}$ Lewis acid was used to prepare an activated cuprate reagent (e.g. $\mathrm{RCu} \bullet \mathrm{BF}_{3}$ ), which was capable of adding to a great number of $\beta$-mono-, $\alpha, \beta$-di-, and $\beta, \beta-$ disubstituted unsaturated esters. We demonstrated that Yamamoto's method worked in our hands by repeating his addition of an activated butyl cuprate to ethyl crotonate. But, when $n$-butyl lithium was replaced with $\alpha$-lithio dimethyl methylphosphonate, the reaction with ethyl crotonate or lactone 1 
failed to give any product. From our search of the literature, one paper ${ }^{14}$ has reported using the same phosphono cuprate that we need in our work; however, it was used for a $S_{N} 2$ substitution reaction. The reason that our attempted reaction have failed is not clear. It is probable that phosphono group decreases the activity of cuprate complex as a nucleophile for 1,4addition reaction.

Higher order cyanocuprates $\left(\mathrm{R}_{2} \mathrm{Cu}(\mathrm{CN}) \mathrm{Li}_{2}\right)$ have also been used for conjugate additions of $\beta$-substituted esters or ketones. Lipshutz reported in his review article $^{12}$ that higher order cyanocuprates can be used for most $\beta$-substituted esters, and even one case of a $\beta, \beta$-disubstituted ketone, but that $\beta, \beta$ disubstituted esters never gave successful conjugate additions. There have been no reports about the use of phosphonomethyl higher order cuprate reagents. The $\alpha$-lithio methylphosphonate $\mathrm{LiCH}_{2} \mathrm{P}(\mathrm{O})(\mathrm{OR})_{2}$ is both a stronger base and probably a better nucleophile than its cuprate derivatives, but in fact it prefers to perform as a base with our electrophilic substrates for which elimination was possible.

Route D (Scheme X), our carbene strategy, does not rely on a conjugate addition reaction to create the quaternary center at the $\beta$-position of our proposed inhibitor. We have tried one model reaction, the addition of the carbene derived from diethyl bromomethyl phosphonate to ethyl crotonate. We predicted that we could generate a carbene (or carbenoid) by ethoxide induced $\alpha$-elimination of $\mathrm{HBr}$ from diethyl bromomethyl phosphonate. In situ reaction with the double bond of ethyl crotonate should form a 
cyclopropane ring (Scheme XI). The reaction gave a new peak by GC; we have been unable to identify this product, but the GC/MS and NMR data clearly show that it is not the desired product. Further literature searching ${ }^{15-17}$ suggest that the best way to produce the necessary phosphono carbene is to decompose the $\alpha$-diazophosphonic ester $(\mathrm{RO}){ }_{2} \mathrm{P}(\mathrm{O}) \mathrm{CHN}_{2}$ (in which $\mathrm{R}$ will be either methyl or ethyl). The anticipated product from carbene addition to lactone 1 has a fused bicyclic 3,6-ring structure. It may be that this bicyclic adduct will be an inhibitor in its own right. However, we anticipate that it can be converted to our original monocyclic inhibitor by a reductive cleavage of the labile bond between the two electron-withdrawing groups on the cyclopropyl ring.

\section{Scheme X}
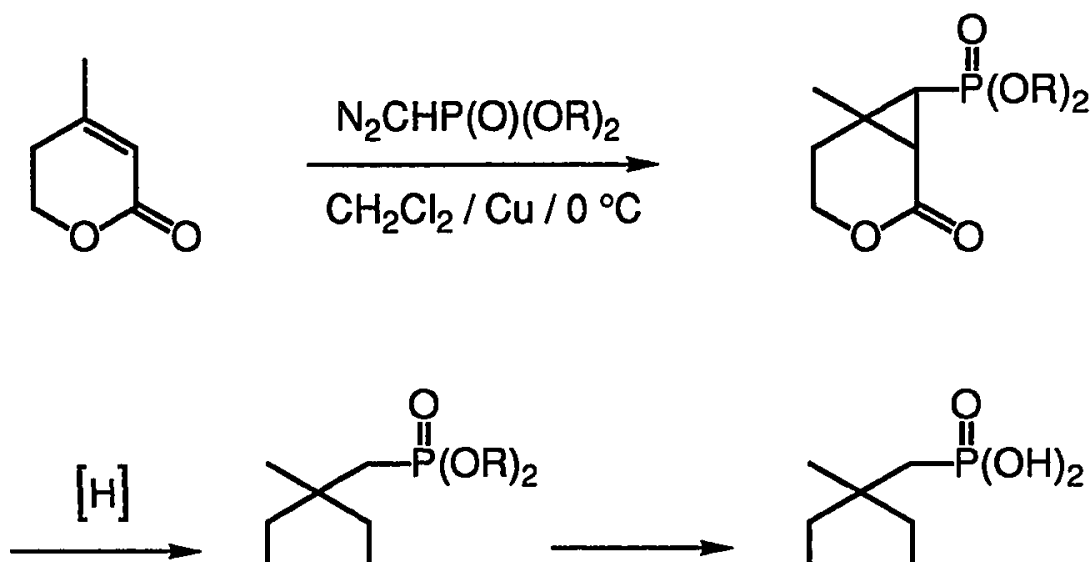<smiles>CC1(CP(=O)(O)O)CCOC(=O)C1</smiles>

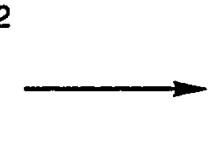<smiles>CC1(CP(=O)(O)O)CCOC(=O)C1</smiles>

$$
\mathrm{R}=\mathrm{CH}_{3} \text { or } \mathrm{CH}_{2} \mathrm{CH}_{3} \text {. }
$$




\section{Scheme XI}

$\sim_{\mathrm{Br}(\mathrm{O})(\mathrm{OEt})_{2}}+\sim_{\mathrm{OEt}}^{\mathrm{O}}$

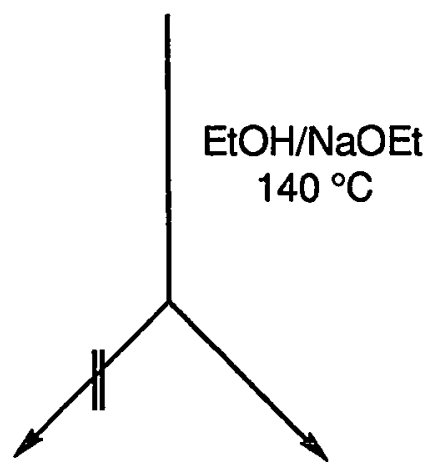

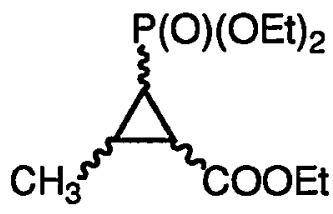

Unidentified

Products 


\section{Conclusion}

Several different approaches to the synthesis of our target inhibitor, 4-methyl-4-phosphonomethyl-3,4,5,6-tetrahydro-2H-pyran-2-one, have been worked on. Although it was well known that conjugate addition to $\beta, \beta-$ disubstituted $\alpha, \beta$-unsaturated ketones or esters is especially difficult, we felt that the directness and simplicity of our plan warranted an exploration of this synthetic strategy. An analysis of our failures, even with Lewis acid activated cuprate reagents, points to further work on those routes in which the elimination of the $\delta$-alkoxy functionality is not possible. Specifically, the "silicon strategy" (Route Bb) still appears to be the most promising approach employing a conjugate addition.

Another synthetic route which should be further explored is the carbene Route D. Finally, Scheme XII outlines a new synthetic plan, which is totally different from the strategies discussed in this thesis. In this route, a DielsAlder reaction will create the troublesome quaternary center in the first step (from starting materials known in the literature ${ }^{18}$ ). This reaction as well as hydrolysis of the product enol ether followed by oxidative removal of an unwanted carbon atom is a sequence which finds direct precedent in Danishefsky's synthesis of pentalenolactone and vernolepin. ${ }^{19}$ A selective sodium borohydride reduction completes the refunctionalization. 


\section{Scheme XI}

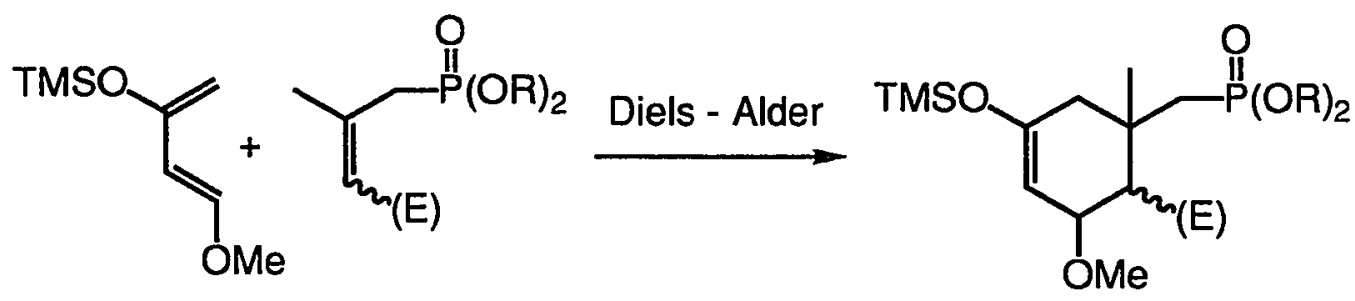<smiles>CC(CC(=O)O)(CC(=O)O)CC(=O)O</smiles><smiles>CC1(CC(=O)O)CC(=O)OC(=O)C1</smiles><smiles>CC(CCO)(CC(=O)O)CC(=O)O</smiles><smiles>[CH+]=C</smiles><smiles>CC1(CP(=O)(O)O)CCOC(=O)C1</smiles>

\footnotetext{
$E=$ Electronwithdrawing Group

$\mathrm{R}=\mathrm{CH}_{3}$ or $\mathrm{CH}_{2} \mathrm{CH}_{3}$

TMS = Trimethylsilyl
} 


\section{Experimental}

General Procedures. Reactions were routinely run under a nitrogen atmosphere with magnetic stirring. Melting points were determined with an electrothermal capillary melting point apparatus and are uncorrected.

IR spectra were recorded on a Perkin-Elmer 710B Infrared Spectrophotometer. Band positions are reported in reciprocal centimeters $\left(\mathrm{cm}^{-1}\right) .{ }^{1} \mathrm{H}$ NMR spectra were recorded on Varian T60, Varian EM 390, or GE QE-300 spectrometers. ${ }^{13} \mathrm{C}$ NMR spectra were recorded on GE QE-300 spectrometer. Chemical shifts are

reported in parts per million ( $\delta$ ) relative to tetramethylsilane. Mass spectra were run on Finnigan Mat 8230. Elemental analyses were performed by Chemical Analysis Service, UC Berkeley.

\section{6-Colorosulfonylimino-3,6-dihydro-4-methyl-2H-pyran (4). ${ }^{20}$ Chlorosulfonyl} isocyanate $(4.25 \mathrm{~g}, 0.03 \mathrm{~mol})$ in absolute ether $(35 \mathrm{~mL})$ was added slowly to isoprene $(2.04 \mathrm{~g}, 0.03 \mathrm{~mol})$ in a $50 \mathrm{~mL}$ round-bottom flask with stirring. The whole mixture was refluxed $6 \mathrm{~h}$, then cooled to $-65^{\circ} \mathrm{C}$ with dry ice and maintained at this temperature for $1 \mathrm{~h}$. The precipitate which was formed with shaking and scratching was removed by filtration, then washed with cold ether to give $1.31 \mathrm{~g}$ crude product ( $20.8 \%$ crude yield). Recrystallization $\left(\mathrm{CH}_{2} \mathrm{Cl}_{2}\right.$ /ether) gave colorless needles: $\mathrm{mp}$ 81-82 ${ }^{\circ} \mathrm{C}$ [lit. $\left.{ }^{20} 81-82{ }^{\circ} \mathrm{C}\right] ; \mathrm{IR}(\mathrm{KBr})$ $1635 \mathrm{~cm}^{-1}(\mathrm{C}=\mathrm{N}) ;{ }^{1} \mathrm{H}$ NMR $\left(60 \mathrm{MHz}, \mathrm{CDCl}_{3}\right) 2.07(\mathrm{~s}, 3 \mathrm{H}), 2.63(\mathrm{t}, \mathrm{J}=6.6 \mathrm{~Hz}, 2 \mathrm{H})$, $4.67(\mathrm{t}, \mathrm{J}=6.6 \mathrm{~Hz}, 2 \mathrm{H}), 6.07$ (s with allylic coupling, $1 \mathrm{H}$ ) ppm.

5,6-Dihydro-4-methyl-2H-pyran-2-one (1). ${ }^{20}$ A solution of compound 4 
$(1.0 \mathrm{~g}, 4.8 \mathrm{mmol})$ in absolute methanol $(2 \mathrm{~mL})$ was refluxed $5 \mathrm{~min}$ on a steam bath. After the solvent was removed in vacuo, water $(2 \mathrm{~mL})$ was added, and the solution was extracted with $\mathrm{CH}_{2} \mathrm{Cl}_{2}(6 \times 2 \mathrm{~mL})$. The combined extracts were dried $\left(\mathrm{MgSO}_{4}\right)$, then concentrated. Vacuum distillation gave $0.5 \mathrm{~g}(93 \%)$ pure product: bp approximately $70-73^{\circ} \mathrm{C} / 0.2 \mathrm{~mm}\left[\right.$ lit. $\left.{ }^{20} 70-72{ }^{\circ} \mathrm{C}\right] ; \mathrm{IR}$ (film) $1760(\mathrm{C}=\mathrm{O}) \mathrm{cm}^{-1}{ }^{1}{ }^{1} \mathrm{H}$ NMR $\left(60 \mathrm{MHz}, \mathrm{CDCl}_{3}\right) 2.02(\mathrm{~s}, 1 \mathrm{H}), 2.38(\mathrm{t}, \mathrm{J}=6.0 \mathrm{~Hz}, 2 \mathrm{H})$, $4.39(\mathrm{t}, \mathrm{J}=6.0 \mathrm{~Hz}, 2 \mathrm{H}$ ), 5.83 (s with allylic coupling, $1 \mathrm{H}$ ) ppm.

\section{Attempted preparation of 4-methyl-4-phosphonomethyl-3,4,5,6-tetrahydro- 2H-pyran-2-one.}

Method A. Sodium $(0.023 \mathrm{~g}, 1 \mathrm{mmol})$ was added to a mixture of benzene $(0.5$ $\mathrm{mL}$ ) and triethylphosphonoacetate $(0.45 \mathrm{~g}, 2 \mathrm{mmol})$. After the sodium had reacted completely, compound $1(0.14 \mathrm{~g}, 1.3 \mathrm{mmol})$ was added to the solution. The mixture was heated at $65^{\circ} \mathrm{C}$ for $2 \mathrm{~h}$, then cooled to room temperature, neutralized with acetic acid (2-3 drops), washed with water ( $2 \mathrm{~mL}), \mathrm{NaHCO}_{3}$ solution $(2 \mathrm{~mL})$, and again with water $(2 \mathrm{~mL})$. The organic layer was dried $\left(\mathrm{MgSO}_{4}\right)$, then concentrated. Column chromatography (silica gel, hexane/ ether gradient) gave a fraction ( $R_{f}=0.31,5 \%$ ether in hexane) which was identified as 2-methyl-1,3-pentadienoic acid (0.02 g, 13.7\%): IR (Nujol) 1690, $1640,1595,1460,1380,1270,1200 \mathrm{~cm}^{-1} ;{ }^{1} \mathrm{H}$ NMR $\left(300 \mathrm{MHz}, \mathrm{CDCl}_{3}\right) 2.04(\mathrm{~d}, \mathrm{~J}=$ $1.2 \mathrm{~Hz}, 3 \mathrm{H}), 5.49(\mathrm{~d}, \mathrm{~J}=11 \mathrm{~Hz}, 1 \mathrm{H}), 5.65(\mathrm{~d}, \mathrm{~J}=17.5 \mathrm{~Hz}, 1 \mathrm{H}), 5.76(\mathrm{~s}, 1 \mathrm{H}), 7.80$ $(\mathrm{dd}, \mathrm{J}=17.5 \mathrm{~Hz}, \mathrm{~J}=11 \mathrm{~Hz}, 1 \mathrm{H}) \mathrm{ppm}$. No further identification was done for other components from the chromatography.

Method B. ${ }^{14}$ A solution of dimethyl methylphosphonate $(0.12 \mathrm{~g}, 1 \mathrm{mmol})$ in dry THF ( $1 \mathrm{~mL})$ was added dropwise to a cooled $\left(-60^{\circ} \mathrm{C}\right)$, stirred solution of 
$n$-butyllithium ( $0.81 \mathrm{~mL}$ of a $1.23 \mathrm{M}$ solution in hexane, $1 \mathrm{mmol}$ ) and dry THF ( $1 \mathrm{~mL})$ under nitrogen. After a few minutes, copper (I) iodide $(0.19 \mathrm{~g}$, $1 \mathrm{mmol}$ ) was added, then the mixture was gradually allowed to warm up to -15 to $-30^{\circ} \mathrm{C}$, and kept at this temperature for $4 \mathrm{~h}$ with efficient stirring. When the copper (I) iodide had practically dissolved, the dark-green to black brown solution was again cooled to $-78^{\circ} \mathrm{C}$ and treated dropwise with a solution of compound $1(0.11 \mathrm{~g}, 1 \mathrm{mmol})$ in THF $(0.5 \mathrm{~mL})$, keeping the temperature below $-60^{\circ} \mathrm{C}$ for $2 \mathrm{~h}$. Finally the reaction mixture was allowed to warm to room temperature overnight. $\mathrm{CH}_{2} \mathrm{Cl}_{2}(5 \mathrm{~mL})$ and water $(10 \mathrm{~mL})$ were added, then mixture was filtered. The organic layer was separated, dried $\left(\mathrm{MgSO}_{4}\right)$, then concentrated. The NMR of the liquid residue $(0.16 \mathrm{~g})$ showed only starting material with no evidence of product formation.

Method C.13 A solution of dimethyl methylphosphonate $(0.50 \mathrm{~g}, 4 \mathrm{mmol})$ in THF $(1 \mathrm{~mL})$ was added dropwise to a cooled $\left(-60^{\circ} \mathrm{C}\right)$, stirred mixture of n-butyllithium solution ( $1.82 \mathrm{~mL}$ of a $2.20 \mathrm{M}$ solution in hexane, $4 \mathrm{mmol}$ ) and dry THF ( $5 \mathrm{~mL}$ ) under nitrogen. After few minutes, copper (I) iodide $(0.76 \mathrm{~g}, 4 \mathrm{mmol})$ was added, the mixture was gradually allowed to warm to -15 to $-30^{\circ} \mathrm{C}$, and kept at this temperature for $2 \mathrm{~h}$ with efficient stirring. When the copper (I) iodide had practically dissolved, the dark-green to black brown solution was again cooled to $-70^{\circ} \mathrm{C}$. Then, boron trifluoride etherate ( $0.6 \mathrm{~mL}, 4 \mathrm{mmol}$ ) was added. After the mixture was stirred for few minutes, compound 1 ( $0.22 \mathrm{~g}, 2 \mathrm{mmol})$ was added. The mixture was allowed to slowly warm to room temperature with stirring and then cooled to $0^{\circ} \mathrm{C}$ with an ice bath. The reaction mixture was quenched with saturated $\mathrm{NH}_{4} \mathrm{Cl}(50 \mathrm{~mL})$ and then extracted with ether $(2 \times 15 \mathrm{~mL})$. The combined organic layers were dried $\left(\mathrm{MgSO}_{4}\right)$, then concentrated. The NMR showed only starting material with 
no evidence of product formation.

\section{Attempted preparation of 3-methyl-3-phosphonomethyl-cyclopentanone.}

Method A. Triethyl phosphonoacetate $(1.12 \mathrm{~g}, 5 \mathrm{mmol})$ was added dropwise to a slurry of sodium hydride ( $0.24 \mathrm{~g}$ of a $50 \%$ oil dispersion, $5 \mathrm{mmol}$ ) in toluene $(20 \mathrm{~mL})$. The reaction mixture was stirred for $1 \mathrm{~h}$ at room temperature until gas evolution had ceased. 3-Methyl-2-cyclopenten-1-one $(0.48 \mathrm{~g}, 5 \mathrm{mmol})$ was added dropwise. The reaction mixture became dark brown on heating at reflux for $2 \mathrm{~h}$. The reaction mixture was quenched with a large excess of water, then extracted with ether $(3 \times 20 \mathrm{~mL})$. The combined ether layers were concentrated to yield $0.87 \mathrm{~g}$ of crude liquid product. Column chromatography (silica gel, hexane/ether gradient) gave a fraction $\left(R_{f}=0.30\right.$, $10 \%$ ether in hexane) which was identified as ethyl (3-methyl-2-cyclopentenylidene)ethanoate. The product was obtained as an E/Z-mixture (50:50) $(0.3 \mathrm{~g}, 5.7 \%):{ }^{1} \mathrm{H}$ NMR $\left(60 \mathrm{MHz}, \mathrm{CDCl}_{3}\right) 1.27(\mathrm{t}, \mathrm{J}=7 \mathrm{~Hz}, 3 \mathrm{H}), 1.98$ (broad singlets, $3 \mathrm{H}$ ), 2.00-3.20 (m, $4 \mathrm{H}), 4.16(\mathrm{q}, \mathrm{J}=7 \mathrm{~Hz}, 2 \mathrm{H}$ ), 5.47, 5.62, 6.00, 7.11 (four broad singlets, $2 \mathrm{H}$ ) ppm. No further identification was done for other components from the chromatography. The aqueous layer was treated with dilute $\mathrm{HCl}$ to $\mathrm{pH} 2-3$, then extracted with ether $(2 \times 30 \mathrm{~mL})$. The combined ether layers were dried $\left(\mathrm{MgSO}_{4}\right)$, then concentrated. A dark brown sticky liquid residue $(0.47 \mathrm{~g}, 47.5 \%)$ was obtained. It was identified as diethyl phosphonoacetic acid (EtO) $)_{2} \mathrm{P}(\mathrm{O}) \mathrm{CH}_{2} \mathrm{COOH}:{ }^{1} \mathrm{H}$ NMR $\left(60 \mathrm{MHz}, \mathrm{CDCl}_{3}\right) 1.33$ $\left(\mathrm{t}, \mathrm{J}_{\mathrm{HH}}=7 \mathrm{~Hz}, 6 \mathrm{H}\right), 3.01\left(\mathrm{~d}, \mathrm{~J}_{\mathrm{PH}}=22 \mathrm{~Hz}, 2 \mathrm{H}\right), 4.11\left(\mathrm{dq}, \mathrm{J}_{\mathrm{HH}}=7 \mathrm{~Hz}, \mathrm{~J}_{\mathrm{PH}}=7 \mathrm{~Hz}, 4\right.$ $\mathrm{H}), 9.10(\mathrm{~s}, 1 \mathrm{H}) \mathrm{ppm}$.

Method B. The cuprate reagent $\mathrm{CuLi}\left[\mathrm{CH}_{2} \mathrm{P}(\mathrm{O})(\mathrm{OMe})_{2}\right]_{2}(1 \mathrm{mmol})$ was 
prepared by same method as described above on $\mathrm{p} 23$ (Method B of attempted preparation of 4-methyl-4-phosphonomethyl-3,4,5,6-tetrahydro-2H-pyran-2one). 3-Methyl-2-cyclopenten-1-one $(0.96 \mathrm{~g}, 10 \mathrm{mmol})$ was added to the cuprate solution at $-78^{\circ} \mathrm{C}$. The same workup procedure as described previously was used to give $0.10 \mathrm{~g}$ of crude liquid residue. The NMR showed only starting material with no evidence of product formation.

4-Benzyloxy-2-butanone (5). ${ }^{21}$ Benzyl alcohol ( $\left.9.72 \mathrm{~g}, 90 \mathrm{mmol}\right)$ and sodium metal $(17 \mathrm{mg}, 0,75 \mathrm{mmol}$ ) were added to $50 \mathrm{~mL}$ two-necked round bottom flask. To this solution, methyl vinyl ketone $(2.13 \mathrm{~g}, 30 \mathrm{mmol})$ was added dropwise in $30 \mathrm{~min}$ at $10-15{ }^{\circ} \mathrm{C}$. The reaction mixture, cooled in an ice-bath, was further stirred for $3 \mathrm{~h}$ and then neutralized with dilute $\mathrm{HCl}$ to $\mathrm{pH} 7$. Following storage overnight in a refrigerator, vacuum distillation gave $1.94 \mathrm{~g}$ of a colorless liquid product (36.1\%): bp $67-68^{\circ} \mathrm{C} / 0.1 \mathrm{~mm}\left[\right.$ lit. $2277-79{ }^{\circ} \mathrm{C} / 0.2$ mm]; IR (film) 3100, 3050, 2880, 1710, 1100, 740, $700 \mathrm{~cm}^{-1} ;{ }^{1} \mathrm{H}$ NMR (60 MHz, $\left.\mathrm{CDCl}_{3}\right) 2.10(\mathrm{~s}, 3 \mathrm{H}), 2.63(\mathrm{t}, \mathrm{J}=6 \mathrm{~Hz}, 2 \mathrm{H}), 3.70(\mathrm{t}, \mathrm{J}=6 \mathrm{~Hz}, 2 \mathrm{H}), 4.47(\mathrm{~s}, 2 \mathrm{H}), 7.27$ $(\mathrm{s}, 5 \mathrm{H}) \mathrm{ppm}$.

Ethyl 5-benzyloxy-3-methyl-2-pentenoate (2a). Triethyl phosphonoacetate $(2.3 \mathrm{~g}, 0.01 \mathrm{~mol})$ was added dropwise to a slurry of sodium hydride $(0.48 \mathrm{~g}$ of a $50 \%$ oil dispersion, $0.01 \mathrm{~mol})$ in dry THF $(20 \mathrm{~mL})$. The reaction mixture was stirred for $1 \mathrm{~h}$ at room temperature until gas evolution had ceased. Compound $5(2.0 \mathrm{~g}, 0.01 \mathrm{~mol})$ was added dropwise at such a rate that the temperature was maintained below $10^{\circ} \mathrm{C}$ (ice bath). Following additional stirring for $15 \mathrm{~min}$ at room temperature, the mixture was taken up in a large 
excess of water and the aqueous solution extracted with ether $(3 \times 50 \mathrm{~mL})$. The combined ether layers were dried $\left(\mathrm{MgSO}_{4}\right)$, then concentrated to yield $2.24 \mathrm{~g}$ of crude liquid residue. The crude product $(0.13 \mathrm{~g})$ was added to hexane $(1 \mathrm{~mL})$, then $\mathrm{CaCl}_{2}(0.9 \mathrm{lg}, 8.2 \mathrm{mmol})$ and $\mathrm{EtOH}(0.84 \mathrm{mg})$ were added to this suspension which was stirred at room temperature overnight. The mixture was filtered, the precipitate was washed with hexane $(1 \mathrm{~mL})$, then the filtrate was concentrated to yield $0.08 \mathrm{~g}(29.8 \%)$ of crude product, which was an $\mathrm{E} / \mathrm{Z}$ mixture (69:31): IR (film) 3100, 3060, 2950, 2870, 1715, 1650, 1220, 1150, 1100, $735,700 \mathrm{~cm}^{-1} ;{ }^{1} \mathrm{H} \mathrm{NMR}\left(60 \mathrm{MHz}, \mathrm{CDCl}_{3}\right) 1.26(\mathrm{t}, \mathrm{J}=7 \mathrm{~Hz}, 3 \mathrm{H}), 1.96(\mathrm{~d}, \mathrm{~J}=1 \mathrm{~Hz}$, $3 \mathrm{H}, \mathrm{Z}), 2.18(\mathrm{~d}, \mathrm{~J}=1 \mathrm{~Hz}, 3 \mathrm{H}, \mathrm{E}), 2.44(\mathrm{t}, \mathrm{J}=7 \mathrm{~Hz}, 2 \mathrm{H}, \mathrm{E}), 3.00(\mathrm{t}, \mathrm{J}=7 \mathrm{~Hz}, 3 \mathrm{H}, \mathrm{Z})$, $3.60(\mathrm{t}, \mathrm{J}=7 \mathrm{~Hz}, 3 \mathrm{H}, \mathrm{E}), 3.65(\mathrm{t}, \mathrm{J}=7 \mathrm{~Hz}, 3 \mathrm{H}, \mathrm{Z}), 4.14(\mathrm{q}, \mathrm{J}=7 \mathrm{~Hz}, 2 \mathrm{H}), 4.50(\mathrm{~s}, 2$ $\mathrm{H}), 5.65-5.83(\mathrm{~m}, 1 \mathrm{H}), 7.30(\mathrm{~s}, 5 \mathrm{H}) \mathrm{ppm}$. Anal. Calcd for $\mathrm{C}_{15} \mathrm{H}_{20} \mathrm{O}_{3}: \mathrm{C}, 72.55 ; \mathrm{H}$, 8.12. Found: $C, 73.61 ; H, 7.88$.

Attempted preparation of 5-benzyloxy-3-methyl-3-phosphonomethyl-2pentanoate.

Method A. Triethyl phosphonoacetate $(0.27 \mathrm{~g}, 1.21 \mathrm{mmol})$ was added dropwise to a slurry of sodium hydride $(0.06 \mathrm{~g}$ of a $50 \%$ oil dispersion, 1.21 $\mathrm{mmol})$ in dry THF $(3.3 \mathrm{~mL})$. The reaction mixture was stirred for $1 \mathrm{~h}$ at room temperature until gas evolution had ceased. Compound 2a $(0.3 \mathrm{~g}, 1.21 \mathrm{mmol})$ was added dropwise. Following additional stirring for $15 \mathrm{~min}$ at room temperature, the mixture was taken up in a large excess of water and the aqueous solution was extracted with ether $(3 \times 15 \mathrm{~mL})$. The combined ether layers were dried $\left(\mathrm{MgSO}_{4}\right)$, then concentrated to yield $0.31 \mathrm{~g}$ of crude liquid residue. The NMR showed only starting material. The same reaction was also run in ethanol, benzene, toluene, and mesitylene respectively. The 
reaction time was extended to $24 \mathrm{~h}$. The NMR showed only starting material, or the elimination product benzyl alcohol, with no evidence of product formation.

Method B. The cuprate reagent $\mathrm{CuLi}\left[\mathrm{CH}_{2} \mathrm{P}(\mathrm{O})(\mathrm{OMe})_{2}\right]_{2}(1 \mathrm{mmol})$ was prepared by same method as described above on p. 23 (Method B of attempted preparation of 4-methyl-4-phosphonomethyl-3,4,5,6-tetrahydro-2H-pyran-2one). Compound $2 \mathrm{a}(0.25 \mathrm{~g}, 1 \mathrm{mmol})$ was added to the cuprate solution at $-78{ }^{\circ} \mathrm{C}$. The same workup procedure as described previously was used to give a crude liquid residue whose NMR showed only starting material with no evidence of product formation.

Method C. A solution of dimethyl methylphosphonate $(0.12 \mathrm{~g}, 1 \mathrm{mmol})$ in dry THF $(0.5 \mathrm{~mL})$ was added dropwise to a cooled $\left(-60^{\circ} \mathrm{C}\right)$ solution of $n$-butyllithium solution $(0.8 \mathrm{~mL}$ of a $1.23 \mathrm{M}$ solution in hexane, $1 \mathrm{mmol})$. After $0.5 \mathrm{~h}$, compound $2 \mathrm{a}(0.25 \mathrm{~g}, 1 \mathrm{mmol})$ was added at $-78^{\circ} \mathrm{C}$. The mixture was gradually allowed to warm to room temperature, then heated at reflux overnight. The reaction mixture was then quenched with excess water and extracted with ether $(2 \times 10 \mathrm{~mL})$. The combined extracts were dried $\left(\mathrm{MgSO}_{4}\right)$ then concentrated to yield $0.17 \mathrm{~g}$ of a crude liquid residue. Column chromatography (silica gel, hexane/ether gradient) gave several fractions, but none of their NMR spectra showed any evidence of product formation or residual starting material.

2,2-Dimethyl-1,3-dioxane-4,6-dione (Meldrum's acid). ${ }^{23}$ Concentrated sulfuric acid $(0.8 \mathrm{~mL})$ was added with stirring to a suspension of powdered malonic acid $(20.8 \mathrm{~g}, 0.2 \mathrm{~mol})$ in acetic anhydride $(24.5 \mathrm{~g}, 0.24 \mathrm{~mol})$. Acetone $(12.76 \mathrm{~g}$, 
$0.22 \mathrm{~mol}$ ) was added at $20-25^{\circ} \mathrm{C}$. The reaction mixture was allowed to stand overnight in a refrigerator. The resulting crystals were filtered and washed three times with ice water. The air dried product (19.2 g, crude yield $72.8 \%$ ) was dissolved in acetone $(40 \mathrm{~mL})$ without heating. On addition of water $(80$ $\mathrm{mL})$, white crystals were obtained $(15.6 \mathrm{~g}, 59.2 \%): \operatorname{mp} 96-98^{\circ} \mathrm{C}\left[\mathrm{lit}^{23} 94-95^{\circ} \mathrm{C}\right]$; IR (Nujol) 1790, 1760, 1210, $1070 \mathrm{~cm}^{-1} ;{ }^{1} \mathrm{H}$ NMR (60 $\left.\mathrm{MHz} \mathrm{CDCl}_{3}\right) 1.78$ (s, $\left.6 \mathrm{H}\right)$, $3.33(\mathrm{~s}, 2 \mathrm{H}) \mathrm{ppm}$.

Attempted preparation of [2-(3-benzyloxy)-butenylidene]-2,2-dimethyl-1,3dioxane-4,6-dione (2c). Following the procedure of Corey ${ }^{24}$, a mixture of Meldrum's acid (1.51 g, $10.4 \mathrm{mmol})$, compound 5 (1.52 g; $10.27 \mathrm{mmol})$ and pyridine $(4 \mathrm{~mL})$ was heated to $65-75^{\circ} \mathrm{C}$ for $12 \mathrm{~h}$. The reaction mixture was poured into water $(20 \mathrm{~mL})$. The solution was neutralized $(\mathrm{pH}=7)$ with dilute $\mathrm{HCl}$, then extracted with ether $(2 \times 20 \mathrm{~mL})$. The combined extracts were dried $\left(\mathrm{MgSO}_{4}\right)$ then concentrated. The NMR showed only starting material, with no evidence of product formation. When same reaction was attempted in either refluxing pyridine with catalytic piperidine or at refluxing temperature of collidine, the elimination product, benzyl alcohol, was obtained.

\section{Attempted preparation of 5-benzyloxy-3-methyl-2-pentenonitrite. ${ }^{11}$}

Compound $5(1.48 \mathrm{~g}, 10 \mathrm{mmol})$, cyanoacetic acid $(0.85 \mathrm{~g}, 10 \mathrm{mmol})$, and ammonium acetate $(0.15 \mathrm{~g}, 2 \mathrm{mmol})$ were dissolved in benzene (10 $\mathrm{mL})$ in a $25 \mathrm{~mL}$ three-necked round bottom flask. The solution was heated to reflux. Water was collected in a Dean-Stark trap over a $2 \mathrm{~h}$ period. Evaporation of the solvent gave a crude product whose NMR showed the elimination product, benzyl alcohol, as the major identifiable product. 
Diethylphosphonobromomethane. ${ }^{25}$ Dibromoethane $(69.5 \mathrm{~g}, 0.40 \mathrm{~mol})$ and triethylphosphite $(86.4 \mathrm{~g}, 0.52 \mathrm{~mol})$ were added to a $250 \mathrm{~mL}$ round bottom flask. The reaction mixture was heated at reflux for $16 \mathrm{~h}$. Distillation of the crude product gave a colorless liquid (10.6 g, $11.5 \%)$ : bp $80^{\circ} \mathrm{C} / 0.2 \mathrm{~mm}$ [lit. 25 $\left.56-58{ }^{\circ} \mathrm{C} / 0.1 \mathrm{~mm}\right]$; IR (film) $3020,1400,1260,1175,1010 \mathrm{~cm}^{-1} ;{ }^{1} \mathrm{H}$ NMR (60 $\left.\mathrm{MHz}_{\mathrm{CDCl}}\right) 1.37\left(\mathrm{t}, \mathrm{J}_{\mathrm{HH}}=7 \mathrm{~Hz}, 6 \mathrm{H}\right), 3.30\left(\mathrm{~d}, \mathrm{~J}_{\mathrm{PH}}=10 \mathrm{~Hz}, 2 \mathrm{H}\right), 4.22$ (quintet, $\left.\mathrm{J}_{\mathrm{HH}}=7 \mathrm{~Hz}, \mathrm{~J}_{\mathrm{PH}}=7 \mathrm{~Hz}, 4 \mathrm{H}\right) \mathrm{ppm}$.

\section{Attempted preparation of diethyl 2-methyl-3-carboethoxycyclopropyl- phosphate. ${ }^{26}$}

Method A. Diethylphosphonobromomethane ( $0.46 \mathrm{~g}, 2 \mathrm{mmol})$, ethyl crotonate $(0.23 \mathrm{~g}, 2 \mathrm{mmol})$ and sodium hydride $(96 \mathrm{mg}$ of a $50 \%$ oil dispersion, $2 \mathrm{mmol}$ ) were added to benzene $(2 \mathrm{~mL})$ in a $5 \mathrm{~mL}$ round bottom flask. The reaction mixture was stirred at room temperature for $3 \mathrm{~h}$. The reaction was quenched with a minimum of methanol, then water was added. The organic layer was separated, washed with water, dried $\left(\mathrm{MgSO}_{4}\right)$, then concentrated. The NMR showed that the ethyl crotonate has been consumed, but that the diethylphosphonobromomethane still remained. There was no evidence of product formation. No further purification, identification, or characterization was done.

Method B. The same reaction as in Method A was run at the same scale at room temperature for $16 \mathrm{~h}$. The difference was the EtOH/Na catalyst and solvent system used. The NMR showed that the starting material ethyl crotonate had disappeared. There was some evidence showing that a new compound had formed, but it was not the desired product. 
Method C. The same reaction as in Method A was run in a 15-mL Ace Glass sealed tube with threaded teflon plug at $140^{\circ} \mathrm{C}$ overnight. The GC showed that there was a major new peak with a retention time $2.65 \mathrm{~min}$. The GC/MS showed major fragment ions at $m / z 131$ (5), 116 (8), 85 (10), 73 (59), 45 (100), 43 (40), which could not be explained by fragmentation of the desired product.

4-Dimethylphenylsilyl-2-butanone (6). ${ }^{9}$ Dimethylphenylchlorosilane $(3.41 \mathrm{~g}$, $20 \mathrm{mmol})$, lithium wire $(0.42 \mathrm{~g}, 60 \mathrm{mmol})$ and dry THF (50 mL) were stirred for $24 \mathrm{~h}$ under nitrogen. The resulting red mixture of dimethylphenylsilyllithium was used for making a cuprate reagent without further purification. Copper (I) iodide $(1.90 \mathrm{~g}, 10 \mathrm{mmol})$ was added to this red mixture at $-23^{\circ} \mathrm{C}$ (dry ice in $\mathrm{CCl}_{4}$ ). Stirring was continued for $4 \mathrm{~h}$ at $-23^{\circ} \mathrm{C}$, then methyl vinyl ketone $(0.70 \mathrm{~g}, 10 \mathrm{mmol})$ was added and the reaction mixture was stirred for another $0.5 \mathrm{~h}$. The mixture was poured onto a mixture of ice ( $300 \mathrm{~g})$ and conc. $\mathrm{HCl}(25 \mathrm{~mL})$, then extracted with ether $(3 \times 100 \mathrm{~mL})$. The combined extracts were filtered, washed successively with $3 \mathrm{M} \mathrm{HCl}(100 \mathrm{~mL})$, water $(100 \mathrm{~mL})$, saturated sodium bicarbonate $(100 \mathrm{~mL})$, and water $(100 \mathrm{~mL})$, then dried $\left(\mathrm{MgSO}_{4}\right)$ and concentrated to give the crude product $(3.54 \mathrm{~g})$. Column chromatography (silica gel, hexane/ether gradient) gave a fraction $\left(\mathrm{R}_{\mathrm{f}}=0.20\right.$, $10 \%$ ether in hexane) which was identified as the product $(0.20 \mathrm{~g}, 10 \%):$ IR (film) $3100,3050,2980,1720,1430,1360,1250,1200,1110,700 \mathrm{~cm}^{-1}$; ${ }^{1} \mathrm{H}$ NMR $(60$ $\left.\mathrm{MHz}, \mathrm{CDCl}_{3}\right) 0.28(\mathrm{~s}, 6 \mathrm{H}), 1.00(\mathrm{t}, \mathrm{J}=8 \mathrm{~Hz}, 2 \mathrm{H}), 2.07(\mathrm{~s}, 3 \mathrm{H}), 2.38(\mathrm{t}, \mathrm{J}=8 \mathrm{~Hz}, 2$ $\mathrm{H}), 7.65(\mathrm{~m}, 5 \mathrm{H}) \mathrm{ppm}$. 
1-Cyano-4-dimethylphenylsilyl-2-methyl-1-butene (2b) and 1-Cyano-4dimethylphenylsilyl-2-methyl-2-butene (mixture). 11 4-Dimethylphenylsilyl2-butanone 6 ( $0.21 \mathrm{~g}, 1 \mathrm{mmol})$, cyanoacetic acid (0.085 g, $1 \mathrm{mmol}$ ), ammonium acetate (15 mg, $0.2 \mathrm{mmol}$ ) and acetic acid (1 drop, glacial) were dissolved in benzene $(5 \mathrm{~mL})$ in a $10 \mathrm{~mL}$ round bottom flask. The solution was heated at reflux. Water was collected in a Dean-Stark trap over a $4 \mathrm{~h}$ period. The organic solvent was removed, then the residue was heated to $190{ }^{\circ} \mathrm{C}$ for a short time (to effect decarboxylation). The crude liquid product was purified by column chromatography (aluminum oxide, $10 \%$ ether in pentane) to gave a fraction $\left(R_{f}=0.18,5 \%\right.$ ether in hexane) which was identified as the desired product $(0.09 \mathrm{~g}, 37.3 \%)$ : IR (solution) 3050, 3000, 2265, $2230 \mathrm{~cm}^{-1}$; ${ }^{1} \mathrm{H}$ NMR (60 $\left.\mathrm{MHz}, \mathrm{CDCl}_{3}\right) 0.28(\mathrm{~s}, 6 \mathrm{H}), 0.7-2.5(\mathrm{~m}), 2.97(\mathrm{~s}, 2 \mathrm{H}), 4.95-5.16(\mathrm{~m}, 1 \mathrm{H}), 5.5(\mathrm{t}, \mathrm{J}=9$ $\mathrm{Hz})$, 7.18-7.66 (m, $5 \mathrm{H})$ ppm; MS (EI, $70 \mathrm{eV}) \mathrm{m} / \mathrm{z} 229\left(\mathrm{M}^{+}, 11.69\right), 135$ (100). 


\section{References and Notes}

1. Kolata, G. Science 1983, 221, 1164.

2. Zubay, G. Biochemistry 2nd Ed.; Macmillan: New York, 1988; p 726.

3. Manitto, P. Biosynthesis of Natural Product; John Wiley: New York, 1981; p 215.

4. Barth, M.; Bellamy, F. D.; Renaut, P.; Samreth, S.; Schuber, F. Tetrahedron $1990,46,6731$.

5. Quistad, G. B.; Cerf, D. C.; Schooley, D. A.; Staak, G. B. Nature 1981, 289, 176.

6. Lindberg, M.; Yuan, C.; deWaard, A.; Bloch, K. Biochemistry 1962, 1, 182.

7. Cornforth, J.W.; Cornforth, R.H.; Popjak, G.; Yengoyan, L. J. Biol. Chem. 1966, 241, 3970.

8. Fleming, I.; Henning, R.; Plaut, H. J. Chem. Soc., Chem. Commun. 1984, 29.

9. Ager, D. J.; Fleming, I.; Patel, S. K. J. Chem. Soc. Perkin I 1981, 2520.

10. House, H. O. Modern Synthetic Reaction; Benjamin: Menlo Park, CA, $1972 ; 150$.

11. Cope, A. C.; D'Addieco, A. A.; Whyte, D. E.; Glickman, S. A. Organic Syntheses, Coll. Vol. 4 1963, 234.

12. Lipshutz, B. M.; Wilhem, R. S.; Kozlowzki, J. A. Tetrahedron 1984, 40, 5005.

13. Yamamoto, Y.; Yamamoto, S.; Yatagai, H.; Ishihara, Y.; Maruyama, K. J. Org. Chem. 1982, 47, 119.

14. Hartke, K.; Kunze, O.; Hoederrath, W. J. Chem. Soc., Chem. Commun. $1985,960$.

15. Seyferth, D.; Marmor, R. S. Tetrahedron Lett. 1970, 2493.

16. Regitz, M.; Anschutz, W. Liebigs Ann. Chem. 1969, 730, 194. 
17. Baron, W. J.; DeCamp, M. R.; Hendrick, M. E.; Jones, Jr., M.; Levin, R. H.; Sohn, M. B. In Carbenes; Jones, Jr., M.; Moss, R. A., Eds.; John Wiley: New York, 1973; Vol. I, p133.

18. Danishefsky, S.; Kitahara, T.; Schuda, P. F. Organic Syntheses. 1983, 61, 147; Preparative Organic Chemistry; Hilgetag, G.; Martini, A, Eds.; John Wiley: New York, 1972; p725.

19. Danishefsky, S.; Hirama, M.; Gombatz, K.; Harayama, T.; Berman, E.; Schuda, P. F. J. Amer. Chem. Soc. 1979, 101, 7020; Danishefsky, S.; Schuda, P.; Kato, K. J. Org. Chem. 1976, 41, 1081; Danishefsky, S. Acc. Chem, Res. 1981, 14, 400.

20. Moriconi, E. J.; Meyer, W. C. J. Org. Chem. 1971, 36, 2841.

21. Elderfield, R. C.; Pitt, B. M.; Wempen, I. J. Amer. Chem. Soc. 1950, 72, 1334.

22. Tanabe, M.; Peters, R. H. Organic Syntheses 1984, 60, 92.

23. Davidson, D.; Bernhard, S.A. J. Amer. Chem. Soc. 1948, 70, 3426.

24. Corey, E. J. J. Amer. Chem. Soc. 1952, 74, 5897.

25. Etemad-Moghadam, G. Tetrahedran 1984, 40, 5153.

26. Hellmuth, E. W.; Kaczyhski, J. A.; Low, J.; McCoy, L.L. J. Org. Chem. 1974, 39,3125 . 


\section{PART II}

\section{A NEW SYNTHESIS OF 10-PHENYLANTHRONE}




\section{Introduction}

In a study of the mechanism of the base-catalyzed conversion of prephenic acid to para-hydroxyphenyllactic acid, a 1,7/1,2-hydride shift sequence followed by decarboxylation and aromatization (Scheme I) has been proposed by our group 1 . Since a one-step 1,6-hydride shift followed by loss of carbon dioxide and aromatization is the currently accepted mechanism, the long term goal of this work is to prove which mechanism is operative. Kinetic studies or isotopic labelling won't help distinguish between these two alternatives. Therefore, we have proposed a series of synthetic analogs (Scheme II) which will answer these questions. The analogs are relatively easy to prepare, yet share all of the essential steric and electronic features of prephenic acid.

The 9,10-dihydroanthracene system was chosen for the model compounds because it accurately models the conformational mobility of the dihydrobenzenoid ring of prephenic acid. Scheme III shows our previous synthetic plan to make these model compounds ${ }^{1}$. This thesis describes a new synthesis of 10-phenylanthrone (Scheme IV) based on the work of Rickborn ${ }^{2}$. The new synthesis is simpler and proceeds in higher yield than the previous two-step synthesis from anthrone ${ }^{1,3}$ or the original synthesis by Baeyer ${ }^{4}$ in 1880. 


\section{Scheme 1}
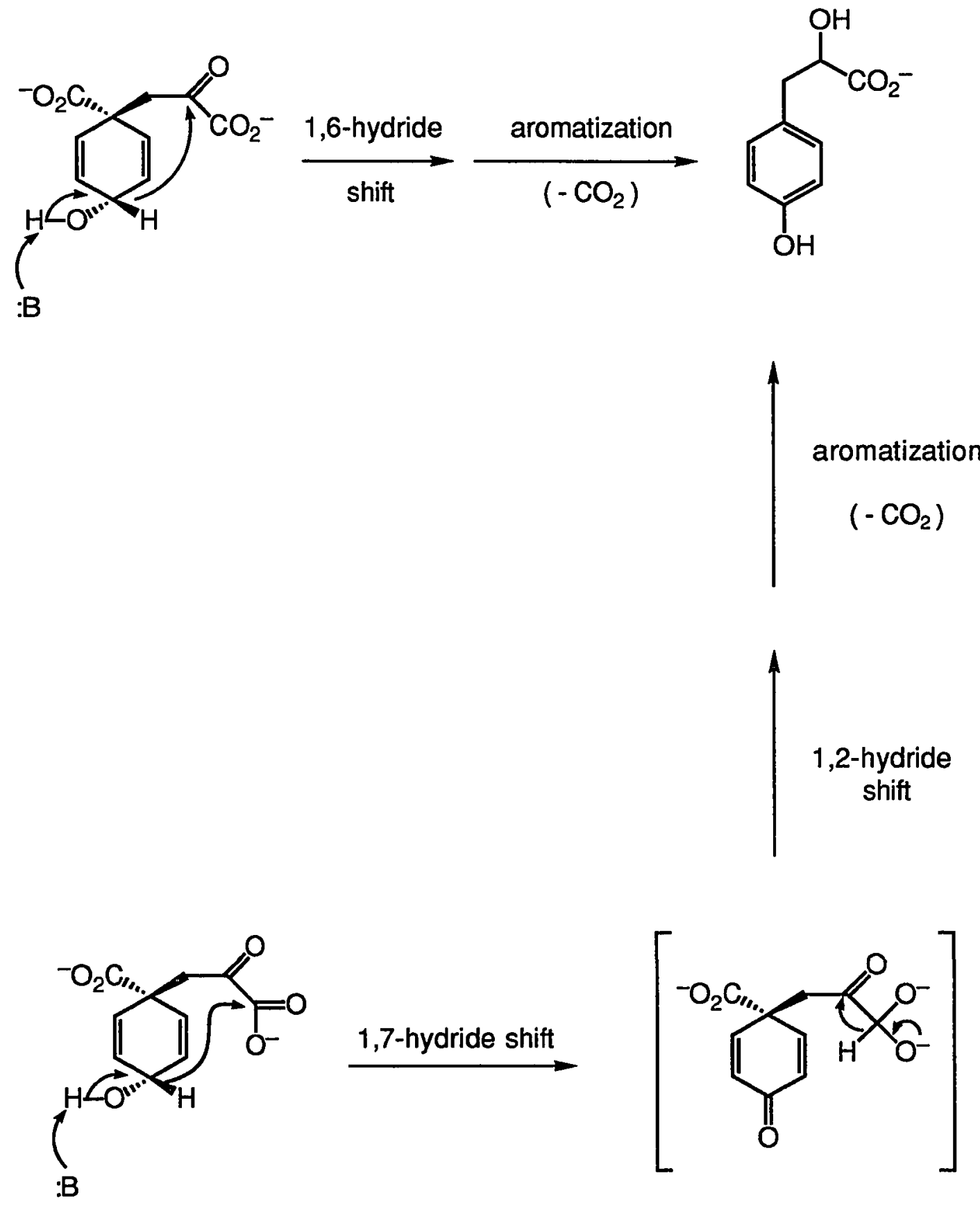

1,7-hydride shift

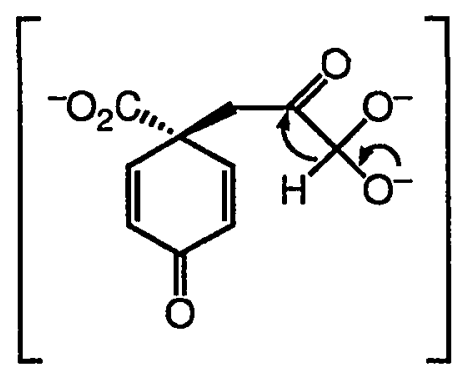




\section{Scheme II}

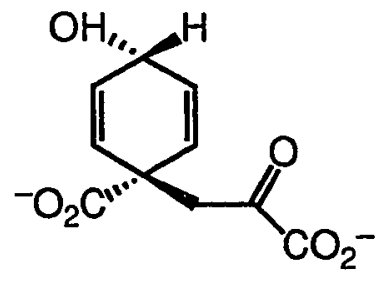

prephenic acid

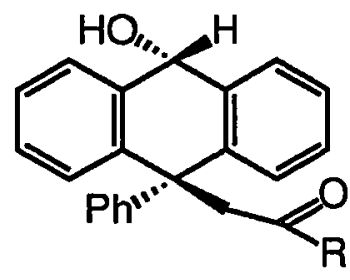

Model I

$\mathrm{R}=\mathrm{H}, \mathrm{Ph}$

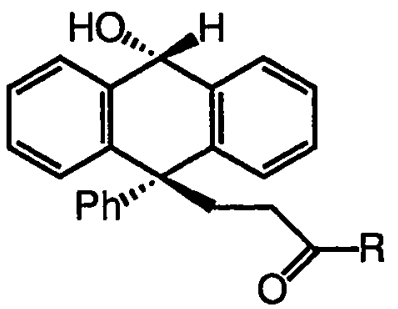

Model II

$\mathrm{R}=\mathrm{H}, \mathrm{OR}$

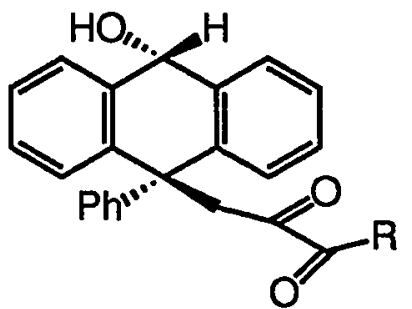

Model III

$\mathrm{R}=\mathrm{H}, \mathrm{OR}, \mathrm{O}^{-}$ 


\section{Scheme III}

model compound I, II, and III

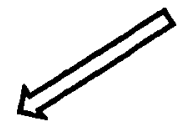<smiles>C=CC[C@]1(c2ccccc2)c2ccccc2[C@@H](O)c2ccccc21</smiles><smiles>C=C</smiles><smiles>C=CCC1(c2ccccc2)c2ccccc2C(=O)c2ccccc21</smiles>

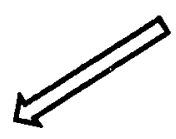<smiles>C=C</smiles><smiles>C=CCOC1c2ccccc2C(c2ccccc2)c2ccccc21</smiles><smiles>C=C</smiles><smiles>O=C1c2ccccc2C(c2ccccc2)c2ccccc21</smiles><smiles>C=C</smiles><smiles>O=C1c2ccccc2Cc2ccccc21</smiles><smiles>[C]=C</smiles><smiles>O=C1c2ccccc2C(Br)c2ccccc21</smiles> 


\section{Scheme IV}

model compound I, II, and III<smiles>C=CC[C@]1(c2ccccc2)c2ccccc2[C@@H](O)c2ccccc21</smiles><smiles>O=C1c2ccccc2C(c2ccccc2)c2ccccc21</smiles><smiles>C=CC=C</smiles><smiles>[X]C1(c2ccccc2)c2ccccc2C(O)c2ccccc21</smiles>

$y$<smiles></smiles><smiles>[C]=C</smiles>

$$
\mathrm{X}=\mathrm{Cl}, \mathrm{Br}
$$<smiles>C=CC=C</smiles>

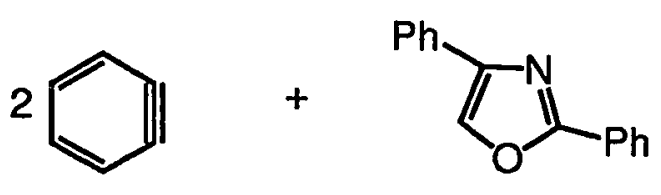




\section{Results and Discussion}

According to the literature, the best and simplest way to synthesize

2,4-diphenyloxazole (1) is the century-old synthesis of Blumlein ${ }^{5}$ and Lewy. ${ }^{6}$

The construction of the oxazole ring is accomplished by condensation of an $\alpha$-halogeno ketone with a primary amide. The method succeeds best when the resulting oxazole contains one or more aryl substituents. In this case, $\alpha$-bromoacetophenone and benzamide give 2,4-diphenyloxazole (1). The condensation reaction was carried out by heating the reactants together at $120-140{ }^{\circ} \mathrm{C}$. The reaction proceeds by $\mathrm{S}_{\mathrm{N}} 2$ displacement of bromide followed by cyclodehydration.

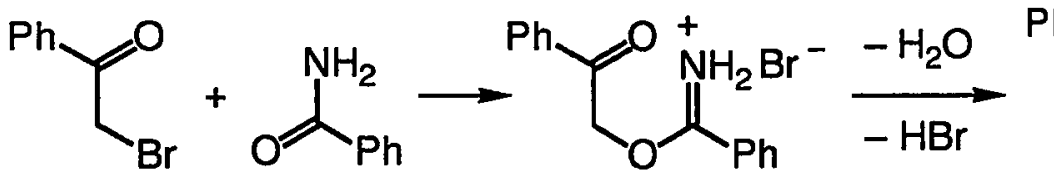<smiles>c1ccc(-c2coc(-c3ccccc3)n2)cc1</smiles>

1

The workup procedure for this reaction was not clear from the previous reports.5,6 In fact, there is only one patent ${ }^{7}$ reporting this method for preparation of 2,4-diphenyloxazole, but again there was no detailed description of the workup procedure. A new purification method was developed in our lab. Preparative column chromatography purification (aluminum oxide, $10 \%$ ether in hexane) was done very easily, because the product has a higher $R_{f}$ value (0.31 on alumina TLC plates with hexane elution) than either starting material or any of the reaction by-products. 
Only the UV data was reported in the literature ${ }^{8,9}$ for 2,4-diphenyloxazole. The IR, ${ }^{1} \mathrm{H}$ NMR (300HZ), ${ }^{13} \mathrm{C}$ NMR $(75 \mathrm{~Hz})$, and GC/MS spectra are reported for the first time in the experimental section (below).

Reddy and Bhatt ${ }^{10}$ first reported cycloaddition of arynes with oxazoles to form 9,10-epoxy-9,10-dihydroanthracene. Benzyne, which acts as a dienophile, was produced by simultaneous addition of anthranilic acid and isoamyl nitrite, which was done by use of a syringe pump. Oxazoles are good dienes for DielsAlder reactions. There are four sequential steps involved in this reaction (Scheme V). Diazotization of anthranilic acid, followed by decarboxylation, leads to the formation of benzyne. Diels-Alder reaction with the oxazole followed by retro-Diels-Alder expulsion of benzonitrile gives 2-phenylisobenzofuran 2 which reacts with a second equivalent of benzyne. Each of the steps must be rapid. Especially, the third step must give isobenzofuran 2 sufficiently rapidly to trap the benzyne as it formed or the benzyne would be lost to alternative reaction. The rate of formation of benzyne is controlled by the rate of addition of anthranillic acid and isoamyl nitrite. The rate of the unimolecular retro Diels-Alder reaction is determined by the reflux temperature of the reaction solvent. Isobenzofurans are quite labile, but they do have a significantly longer lifetime than benzyne. The reaction temperature can affect the formation of the final product. Not only must it be high enough to generate the isobenzofuran, but it cannot be so high that the isobenzofuran decomposes prior to its reaction with benzyne. In this case, the temperature has to be at the reflux temperature of dioxane. 


\section{Scheme V}
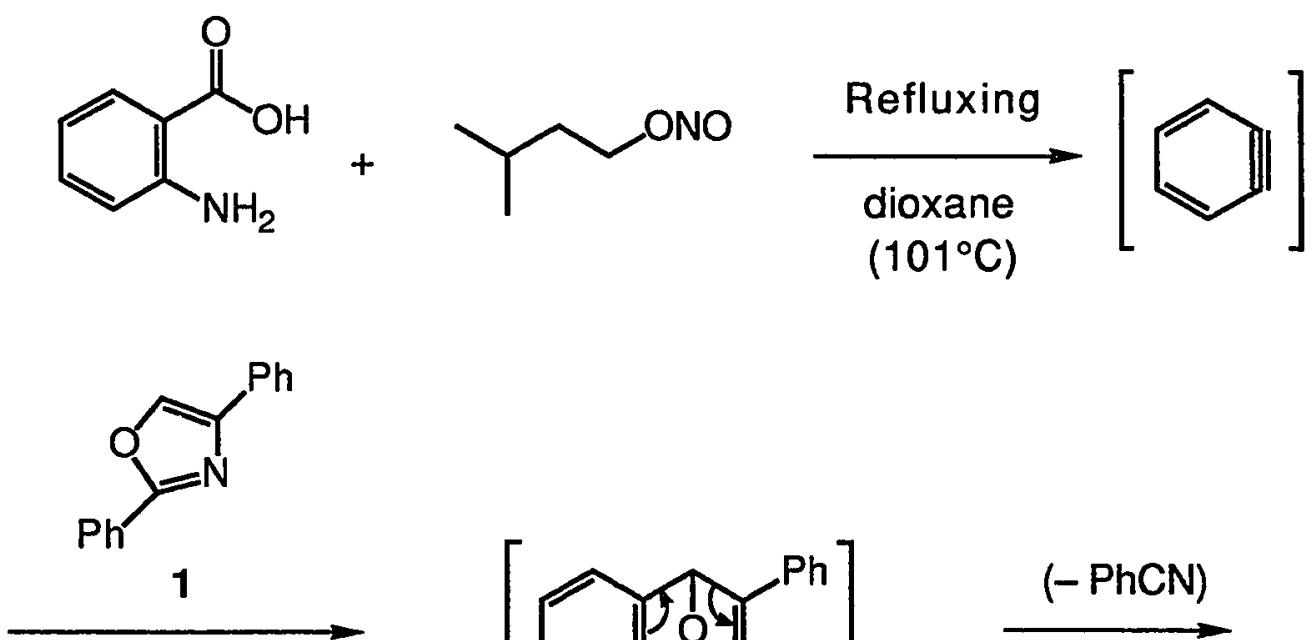

Refluxing dioxane

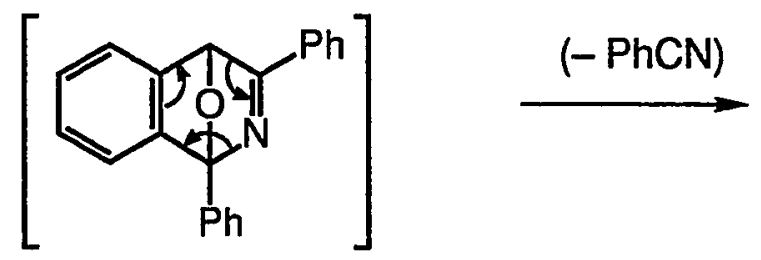<smiles></smiles><smiles>[AlH2]</smiles><smiles>[GeH3]</smiles><smiles>c1ccc(C2C3c4ccccc4-c4ccccc4C2c2ccccc23)cc1</smiles><smiles>C[CH+]C</smiles><smiles>O=C1c2ccccc2C(I)c2ccccc21</smiles> 
9,10-Epoxy-9,10-dihydro-10-phenylanthracene (3) is not known in the literature. We have fully characterized this compound by elemental analysis, IR, ${ }^{1} \mathrm{H}$ NMR $(300 \mathrm{~Hz})$ and ${ }^{13} \mathrm{C}$ NMR $(75 \mathrm{~Hz})$. Compound 3 readily rearranges with acid catalysis to form 10-phenylanthrone (4) quantitatively. 10-phenylanthrone is a very important intermediate in our existing methodology to synthesize prephenic acid model compounds. From previous work in our lab, it is known that 10-phenylanthrone (4) can be produced with a two-step procedure in low yield (best case is $12.5 \%$ overall). 1,3 Our new synthesis of 10-phenylanthrone requires a syringe pump, but proceeds reproducibly in much higher yields (26.3\%).

Even more important is the likelihood that new synthetic methodology may be found to convert the 9,10-epoxide 3 directly into our key intermediate, 10-allyl-9.10-dihydro-10-phenyl-9-trimethylsilyloxyanthracene (5) (Scheme VI).

We hope to be able to avoid the use of 10-phenylanthrone (a reasonably airsensitive intermediate) by use of an "allyl anion synthon." In our first attempt to synthesize 10-allyl-9,10-dihydro-9-hydroxy-10-phenylanthracene, trimethylallylsilane was used as the source of the "allyl anion." There was no reaction with compound 3 even in refluxing ethanol. We next tried to catalyze this reaction by using acid catalysts to weaken the ether linkage to the trityl carbon. Proton acids, such as hydrogen chloride and toluenesulfonic acid, failed to catalyze the desired reaction. Instead, the rearrangement product 10-phenylanthrone was obtained. Lewis acids, such as boron trifluoride etherate, or aluminum chloride, also failed to lead to desired 
product. Instead, anthraquinone (34.9\%) and some other unidentified products were obtained.

Finally fluoride ion is another choice of catalyst ${ }^{11}$ for this reaction. Fluoride forms very strong bonds to silicon (and tin). We expect that fluoride will attack silicon to form a hypervalent structure with enhanced nucleophilicity.

$$
\mathrm{CH}_{2}=\mathrm{CHCH}_{2} \mathrm{Si}(\mathrm{Me})_{3}+\mathrm{F}^{-} \longrightarrow \mathrm{CH}_{2}=\mathrm{CHCH}_{2} \mathrm{Si}-\mathrm{F}
$$

This type of pentavalent fluoride adduct has been shown to work well with ketones and aldehydes. ${ }^{12}$ We haven't yet tried this approach in our lab.

Tetraallyltin is another choice of nucleophile. Tin alkyls are known to be more reactive than the corresponding silanes. The carbon-tin bond has relatively more anionic character on carbon and it has a weaker bond to the metal center. We followed the method of $\mathrm{O}^{\prime} \mathrm{Brien}^{13}$ to synthesize tetraallyltin. Our distilled tetraallyltin was contaminated with some chlorotriallyltin (proved by $60 \mathrm{MHz}$ and $90 \mathrm{MHz}$ NMR), but we decided to use this material for a trial reaction. However, the attempted reaction of tetraallyltin with compound 3 failed to give the desired compound 5. Instead some unidentified products were formed. The reason for this failure is not clear. Fluoride catalysis should be tried with this tin reagent for the same reasons cited above for the silicon reagent. 


\section{Conclusion}

We have worked on new approaches to improving and inventing synthetic methodology leading to 10-phenylanthrone and 10-allyl-9,10-dihydro-9hydroxy-10-phenylanthracene. A new procedure for the preparation of 2,4-diphenyloxazole was developed. 9,10-Epoxy-9,10-dihydro-10phenylanthracene (3) was successfully synthesized and converted to 10phenylanthrone (in $26.3 \%$ overall yield from benzamide) from the DielsAlder reaction of oxazole with benzyne followed by rearrangement with acid catalysis. Several attempts to prepare 10-allyl-9,10-dihydro-9-hydroxy-10phenylanthracene have failed. The use of fluoride as a catalyst is the most promising lead for future workers. Selectively opening the ether linkage in compound 3 without rearrangement is a pivotal reaction in shortenening the synthetic routes to our prephenic acid model compounds. 


\section{Experimental}

General Procedures: See general procedures in the Experimental section of Part I.

2, 4-Diphenyloxazole (1). Benzamide ( $9.95 \mathrm{~g}, 0.05 \mathrm{~mol})$ and $\alpha$-bromoacetophenone $(12.11 \mathrm{~g}, 0.1 \mathrm{~mol})$ were added to a $125-\mathrm{mL}$ Erlenmeyer flask. The mixture was stirred and heated at $130-140{ }^{\circ} \mathrm{C}$ for $3-4 \mathrm{~h}$. The reaction mixture was cooled, then dissolved in ethyl ether $(100 \mathrm{~mL})$ and $\mathrm{H}_{2} \mathrm{O}(40 \mathrm{~mL})$. The aqueous layer was extracted with ethyl ether $(2 \times 50 \mathrm{~mL})$. The combined ether layers were dried $\left(\mathrm{MgSO}_{4}\right)$, then concentrated. The crude product (16.5 g) was dissolved in ether $(100 \mathrm{~mL})$. Residual benzamide $(2.27 \mathrm{~g})$ which is insoluble in ether, was removed by filtration. The ether solution was concentrated to a volume of $20 \mathrm{~mL}$. The light yellow crystals $(3.99 \mathrm{~g}$ ) which formed were collected by filtration and washed with cold ethanol. Purification by column chromatography (aluminum oxide, $10 \%$ ether in hexane) yielded another $3.80 \mathrm{~g}$ of product. The total yield was $7.80 \mathrm{~g}(70.4 \%)$. Analytical samples were crystallized from hexane or ethanol: $\mathrm{mp}$ 103.5-104 ${ }^{\circ} \mathrm{C}$ [lit. $\left.8,9 \mathrm{mp} 103{ }^{\circ} \mathrm{C}\right]$; IR (Nujol) 2950, 1580, 1140, 1080, 780, 760, $710 \mathrm{~cm}^{-1} ;{ }^{1} \mathrm{H}$ $\operatorname{NMR}\left(300 \mathrm{MHz}, \mathrm{CDCl}_{3}\right)$ 7.25-7.50 (m, $\left.6 \mathrm{H}\right), 7.75-7.85(\mathrm{~m}, 2 \mathrm{H}), 7.91(\mathrm{~s}, 1 \mathrm{H})$,

8.05-8.15 (m, $2 \mathrm{H}$ ) ppm; ${ }^{13} \mathrm{C} \mathrm{NMR}\left(75 \mathrm{MHz}, \mathrm{CDCl}_{3}\right.$ ) 125.73 (d), 126.61 (d), 127.60 (s), 128.20 (d), 128.84 (two overlapping resonances-both doublets), 130.48 (d), 131.23 (s), 133.54 (d), 142.09 (s), 162.01 (s) ppm; MS (EI, $70 \mathrm{eV}) \mathrm{m} / \mathrm{z} 221\left(\mathrm{M}^{+}\right.$, 100), 193 (82), 89 ( 97 ). 
9,10-Epoxy-9,10-dihydro-10-phenyl-anthracene (3). The procedure of Reddy and Bhatt ${ }^{6}$ was followed. A three-necked flask fitted with a reflux condenser was charged with 2, 4-diphenyloxazole (1) $(2.21 \mathrm{~g}, 10 \mathrm{mmol})$ and dioxane (20 $\mathrm{mL})$. The solution was brought to reflux, then solutions of anthranilic acid $(4.11 \mathrm{~g}, 30 \mathrm{mmol})$ in dioxane $(20 \mathrm{~mL})$ and isoamyl nitrite $(3.35 \mathrm{~g}, 30 \mathrm{mmol})$ in dioxane $(20 \mathrm{~mL})$ were added simultaneously via syringe pump over a period of $1 \mathrm{~h}$. Heating was continued for $1 \mathrm{~h}$ after the addition was completed. The mixture was cooled, then ether $(50 \mathrm{~mL})$ was added, followed by $3 \mathrm{M} \mathrm{NaOH}$ solution (ca. $50 \mathrm{~mL}$ ). The layers were separated, and the aqueous phase was washed twice with small volumes of ether. The combined organic layers were dried $\left(\mathrm{MgSO}_{4}\right)$ and concentrated to give a dark oily residue which by NMR consisted mainly of compound 3 and benzonitrile. This oily residue was dissolved in hot ethanol $(20 \mathrm{~mL})$, then water was slowly added until the solution started turn cloudy. Finally, a few drops of ethanol were added to clarify the solution. The solution was cooled and scratched until crystals

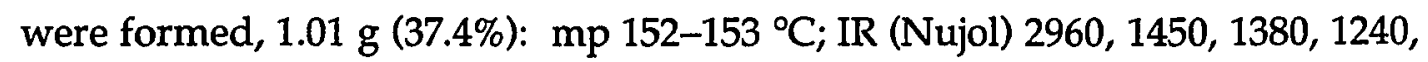
$1180,760,700 \mathrm{~cm}^{-1},{ }^{1} \mathrm{H} \mathrm{NMR}\left(300 \mathrm{MHz} \mathrm{CDCl}_{3}\right) 6.18$ (s, $\left.1 \mathrm{H}\right), 6.95-7.10(\mathrm{~m}, 4 \mathrm{H})$, 7.25-7.60 (m, $7 \mathrm{H}), 7.84(\mathrm{~d}, \mathrm{~J}=8.5 \mathrm{~Hz}, 2 \mathrm{H}) \mathrm{ppm} ;{ }^{13} \mathrm{C} \mathrm{NMR}(75 \mathrm{MHz}, \mathrm{CDCl} 3)$ 81.37 (d), 92 (s), 120.33 (two overlapping resonances-both doublets), 125.76 (d), 125.92 (d), 126.41 (d), 128.18 (d), 128.72 (d), 135.03 (s), 149.13 (s) ppm, one quaternary carbon not observed; Anal. Calcd for $\mathrm{C}_{20} \mathrm{H}_{14} \mathrm{O}$ : C, 88.86; $\mathrm{H}, 5.22$; Found: $\mathrm{C}, 88.76 ; \mathrm{H}, 4.91$.

10-Phenylanthrone (4). Compound $3(20 \mathrm{mg}, 0.07 \mathrm{mmol})$ was dissolved in methylene chloride $(0.5 \mathrm{~mL})$. One small crystal of toluenesulfonic acid was 
added. The solution turned red, then green. After about $0.5 \mathrm{~h}$ at room temperature, the solvent was removed with a gentle stream of nitrogen. The product was obtained in $100 \%$ yield as a single spot by TLC (silica gel, $10 \%$ ether in hexane) (there was one small spot on the baseline from the catalyst, toluenesulfonic acid): $\mathrm{mp} 80^{\circ} \mathrm{C}$ (dec.) [lit. $\left.{ }^{3} 139-140^{\circ} \mathrm{C}\right]$; IR (film) 1660 , $1605 \mathrm{~cm}^{-1} ;{ }^{1} \mathrm{H}$ NMR $\left(90 \mathrm{MHz}, \mathrm{CDCl}_{3}\right) 5.36(\mathrm{~s}, 1 \mathrm{H}), 6.95-7.55(\mathrm{~m}, 11 \mathrm{H}), 8.15-8.50$ (m, $2 \mathrm{H})$ ppm.

\section{Attempted preparation of 10-allyl-9.10-dihydro-10-phenyl-9-trimethyl- silyloxyanthracene (5). Compound $3(27 \mathrm{mg}, 0.1 \mathrm{mmol})$ and trimethyl- allylsilane (22.8 mg, $0.2 \mathrm{mmol}$ ) was dissolved in $\mathrm{CH}_{2} \mathrm{Cl}_{2}(1 \mathrm{~mL})$. The solution was cooled to $-78^{\circ} \mathrm{C}$, then 1 drop of boron trifluoride etherate was added. The reaction mixture was stirred for $2 \mathrm{~h}$, then allowed to warm to room temperature. The NMR showed no evidence of product formation. The major component which could isolated by column chromatography (silica gel, $10 \%$ ether in hexane) was anthraquinone $(14.5 \mathrm{mg}, 34.8 \%)$.}

Tetraallyltin. The method of O'Brien ${ }^{13}$ was followed. Distillation gave $1.88 \mathrm{~g}$ of a mixture of tetraallyltin (66.7\%) and chlorotriallyltin (33.3\%) (the mole percentages were obtained from NMR integration): bp $68-70^{\circ} \mathrm{C} / 0.8 \mathrm{~mm}$ [lit. ${ }^{12}$ $52{ }^{\circ} \mathrm{C} / 0.2 \mathrm{~mm}$ for tetraallyltin]; IR (film) 3110, 3000, 2950, 2770, 1630, 1430, 1195, $1110,1030,880 \mathrm{~cm}^{-1} ;{ }^{1} \mathrm{H}$ NMR $\left(60 \mathrm{MHz}, \mathrm{CDCl}_{3}\right) 1.90(\mathrm{~d}, \mathrm{~J}=8 \mathrm{~Hz}$, tetraallyltin), $2.32(\mathrm{~d}, \mathrm{~J}=8 \mathrm{~Hz}$, chlorotriallyltin), 4.6-5.3 (m), 5.5-6.3 (m). 


\section{References and Notes}

1. Branz, S. E.; Carr, J. A.; Jin, K., San Jose State University, unpublished results.

2. Whitney, S. E.; Winters, M.; Rickborn, B. J. Org. Chem. 1990, 55, 929.

3. Branz, S. E.; Carr, J. A. Synth. Commun. 1986, 16, 141.

4. Baeyer, A. Liebigs Ann. Chem. 1880, 202, 36.

5. Blumlein, F. O. Chem.Ber. 1884, 17, 2578.

6. Lewy, M. Chem.Ber. 1887, 20, 2576; 1888, 21, 924.

7. Sues, O.; Neugebauer, W.; Lind, E.; Klueplel K. W. U.S. Patent 3257 203, 1966; Chem. Abstr. 1966, 65, 16973 h.

8. CRC Atlas of Spectral Data and Physical Constants for Organic Compounds; Grassell, J. G.; Ritchey, W. M. Eds.; CRC Press: Cleveland, 1975; Vol. III, p 726.

9. CRC Handbook of Data on Organic Compound; Weast, R. C.; Astle, M. J., Eds.; CRC Press: Boca Raton, 1985; Vol. III, p 948.

10. Reddy, G. S.; Bhatt, M. V. Tetrahedron Lett. 1980, 3627.

11 Fluoride ion is usually supplied as the THF-soluble salt tetrabutyl ammonium fluoride (TBAF).

12. Carey, F. A.; Sundberg, R. J. Advanced Organic Chemistry; Plenum: New York, 1990; Part B, p 469.

13. O'Brien, S.; Fishwick, M.; McDermott, B.; Wallbridge, M. G. H.; Wright, G. A. Inorganic Synthesis 1972, 13, 75.

14. The literatures 15,16 disagree on the interpretation of the NMR spectrum. It may be caused by unpurified samples containing triallyltin chloride, which cannot be separated by distillation. The coupling between tin and the allylic methylene hydrogens was reported to have a coupling constant of 63 in ref. 15. In agreement with ref. 16, we did not observe any such coupling; the only additional NMR resonances were due to triallyltin chloride. 
15. Blears, D. J.; Danyluk, S. S.; Cawley, S. J. Organomet. Chem. 1966, 6, 284.

16. Fishwick, M.; Wallbridge, M. G. H. J. Organomet. Chem. 1970, 25, 69. 